\title{
The role of potential vorticity anomalies in the Somali Jet on Indian summer monsoon intraseasonal variability
}

Article

Accepted Version

Rai, P., Joshi, M., Dimri, A. P. and Turner, A. (2018) The role of potential vorticity anomalies in the Somali Jet on Indian summer monsoon intraseasonal variability. Climate Dynamics, 50 (11-12). pp. 4149-4169. ISSN 0930-7575 doi: https://doi.org/10.1007/s00382-017-3865-9 Available at https://centaur.reading.ac.uk/68484/

It is advisable to refer to the publisher's version if you intend to cite from the work. See Guidance on citing.

To link to this article DOI: http://dx.doi.org/10.1007/s00382-017-3865-9

Publisher: Springer

Publisher statement: The DOI will be: 10.1007/s00382-017-3865-9

All outputs in CentAUR are protected by Intellectual Property Rights law, including copyright law. Copyright and IPR is retained by the creators or other copyright holders. Terms and conditions for use of this material are defined in the End User Agreement.

www.reading.ac.uk/centaur 
Central Archive at the University of Reading

Reading's research outputs online 


\section{(1)}

\section{The role of potential vorticity anomalies in the Somali Jet on Indian Summer Monsoon}

\section{Intraseasonal Variability}

$$
\text { P. Rai }{ }^{\circledR}, \text { M. Joshi }{ }^{\# \dagger} \text {, A. P. Dimri }{ }^{\circledR, *} \text { and A. G. Turner }{ }^{\$}
$$

${ }^{\circledR}$ School of Environmental Sciences, Jawaharlal Nehru University, New Delhi, India

${ }^{\#}$ Centre for Ocean and Atmospheric Sciences, University of East Anglia, Norwich, UK

${ }^{\dagger}$ Climatic Research Unit, University of East Anglia, Norwich, UK

\$NCAS-Climate and Department of Meteorology, University of Reading, Reading, UK

${ }^{*}$ For Correspondence: Prof. A. P. Dimri, School of Environmental Sciences, Jawaharlal Nehru

University, New Delhi, India, 110067. Email: apdimri@hotmail.com

(1)

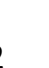

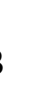

4

(1)

6




\section{Abstract}

The climate of the Indian subcontinent is dominated by rainfall arising from the Indian summer monsoon (ISM) during June to September. Intraseasonal variability during the monsoon is characterized by periods of heavy rainfall interspersed by drier periods, known as active and break events respectively. Understanding and predicting such events is of vital importance for forecasting human impacts such as water resources. The Somali Jet is a key regional feature of the monsoon circulation. In the present study, we find that the spatial structure of Somali Jet potential vorticity (PV) anomalies varies considerably during active and break periods. Analysis of these anomalies shows a mechanism whereby sea surface temperature (SST) anomalies propagate north/northwestwards through the Arabian Sea, caused by a positive feedback loop joining anomalies in SST, convection, modification of PV by diabatic heating and mixing in the atmospheric boundary layer, wind-stress curl, and ocean upwelling processes. The feedback mechanism is consistent with observed variability in the coupled ocean-atmosphere system on timescales of approximately 20 days. This research suggests that better understanding and prediction of monsoon intraseasonal variability in the South Asian monsoon may be gained by analysis of the day-to-day dynamical evolution of PV in the Somali Jet.

Keywords: Indian Summer Monsoon (ISM), Somali Jet, Potential vorticity, Wind-stress curl, Intraseasonal variability 


\section{Introduction}

The summer monsoon during June to September (JJAS) is the chief contributor to total annual rainfall over the Indian subcontinent, through major rain-yielding systems such as monsoon depressions, the monsoon trough, offshore vortices, mid-tropospheric cyclones, as well as orographic rainfall over the Western Ghats. Rainfall is strongest during July and August (JA hereafter). Since Indian society is so finely tuned to the timing and intensity of the monsoon, any variations on time scales ranging from the intraseasonal to the interdecadal have huge impacts on a range of socio-economic sectors, mainly in agriculture, health and industry. The study of monsoon intraseasonal variability with its characteristic active and break periods of enhanced and reduced rainfall, each lasting several days or a week or more, is therefore of great importance for the Indian subcontinent.

Widespread research efforts (Rodwell, 1997; Krishnan et al., 2000; Krishnamurthy and Shukla, 2000, 2007, 2008; Gadgil and Joseph, 2003; Rajeevan et al., 2006, 2010; Maharana and Dimri, 2015) have shown how intra-seasonal variability (ISV) is expressed as active and break spells over the central Indian region during the monsoon (Goswami, 2005). Intraseasonal oscillations (ISOs) operating on time scales of around 30-60 days are accountable for much of the active and break events, in addition to the more widely recognized role played by external forcing such as the El Niño Southern Oscillation (ENSO), which adds a seasonal mean anomaly covering much of the country (Krishnamurthy and Shukla, 2000). The total amount of monsoon rainfall can be influenced by the length and relative frequency of active and break spells, which is primarily determined by the ISOs and their spatiotemporal evolution (Goswami, 2005; Sperber et al., 2000). 
Forcing from sea-surface temperatures (SST) plays a very important role in monsoon variability, through e.g. ocean mixing in the Arabian Sea lowering SSTs and reducing convection and rainfall (Shenoi et al., 2002). Izumo et al. (2008) found variability in rainfall in western India was related to SST via variations in moisture transport associated with reduced upwelling off the Oman and Somali coasts. Further south, higher SSTs in the Seychelles-Chagos thermocline ridge region south of the equator cause reductions in upwelling, which are related to anomalously weak south-westerlies in late spring. Vecchi and Harrison (2004) showed a similar relationship between colder SST anomalies in the western Arabian Sea and decreased rainfall along the Western Ghats in June and July. In the Bay of Bengal, observations from BOBMEX observations have shown lowered SST during active phases of convection (Bhat, 2001).

On intraseasonal scales, observations from moored buoys suggest that SST varies primarily in response to variations in convection, decreasing in active spells and increasing in cloud free conditions (Premkumar et al., 2000). More detailed analysis reveals a quadrature relationship between Bay of Bengal SST and convection (with SST anomalies peaking 10-15 days before convective anomalies; Vialard et al., 2011; Jayakumar et al., 2016). The interaction of ocean with atmosphere during active and break cycle has been studied by Joseph and Sabin (2008). They observed the maximum positive SST anomaly value over north BoB prior to the beginning of an active-break cycle. At this time, the positive SST anomaly zone extends from the Arabian Sea to about longitude $150^{\circ} \mathrm{E}$ in the west Pacific Ocean which gives the mean SST anomaly of 11 active-break cycles in the 8 pentads (of an average active-break cycle of period 40 days). In the SST gradient area to the south of maximum SST anomaly, a convective cloud band forms after about a pentad that in the following 2-3 days generates an LLJ through peninsular India and the active phase of the monsoon begins. The cloud band thus formed 
(reducing the incident solar radiation) and the strong winds of the LLJ (by causing evaporation at the ocean surface) cools the ocean there, when the convection weakens and the LLJ moves south to an equatorial location in the Indian Ocean which has warmer SST, where a new cloud band forms. This is the break monsoon phase.

The studies by Findlater $(1969,1977)$ and Hart et al. (1978) define the East African Jet (EAJ) and Somali Jet systems (henceforth we will describe these together as the Somali Jet) as the critical elements of the low-level flow that supply the necessary moisture for supporting Indian monsoon rains (Murakami et al., 1984), and are part of a circulation system that is set up by the large-scale meridional tropospheric temperature gradient (Xavier et al., 2007). Any changes in the temperature gradient can thus change the circulation pattern, leading to variations in seasonal rainfall and timing of monsoon onset (Findlater, 1969). For instance, using monthly mean winds Findlater (1971) showed that the LLJ splits into two branches over the Arabian Sea, the northern branch intersecting the west coast of Indian near $17^{\circ} \mathrm{N}$, while the southerly branch passes eastward just south of India.

Krishnamurti et al. (1976) simulated the Somali Jet and its interaction with features such as the orography over East Africa and Madagascar, using an imposed lateral forcing at $75^{\circ} \mathrm{E}$ to represent the meridional land-ocean contrast in heating, essentially following Murakami et al. (1970). Krishnamurti et al. (1976) concluded that the broad-scale Somali Jet was forced by the land-ocean contrast in heating in this region, and barotropic instability was ascribed as a possible mechanism for the splitting the Jet over the Arabian Sea. A study by Krishnan et al. (2000) suggested that forcing by suppressed convection anomalies over the Bay of Bengal leads to the development of low-level anticyclonic circulation anomalies as a Rossby wave response, which then propagate northwestward to initiate the monsoon break over India. 
Potential vorticity (PV) is an important quantity in the low-level monsoon circulation as identified by Yang and Krishnamurti (1981); they assigned negative PV found in the Arabian Sea north of the equator to advection from the southern hemisphere associated with the largescale monsoon circulation. Hoskins and Rodwell (1995) and Rodwell and Hoskins (1995) studied the Somali Jet using a time-dependent primitive equation model with specified zonal flow, mountains and diabatic heating, and showed how symmetric instabilities might be induced by the transport of negative potential vorticity from the southern hemisphere into the atmosphere overlying the Arabian Sea. Their study and others (e.g. Slingo et al., 2005) noted the importance of the East African Highlands in confining the cross-equatorial flow into a zonally narrow jet. Rodwell and Hoskins (1995) suggested that frictional and diabatic heating provided the mechanism for material modification of PV within the Somali Jet and were essential in sustaining it. They noted the strong sensitivity of the Somali Jet to changes in convective heating over the southern Indian Ocean and that small modifications to PV led to anticyclonic circulation of the Somali Jet over the Arabian Sea with a tendency of the flow to turn southeastward and avoid India. According to them, the particles that retain their negative PV over the Arabian Sea tend to recirculate back into the southern hemisphere, reducing moisture fluxes into the Indian subcontinent.

A number of studies have appeared related to the variability in Somali Jet at interannual and intraseasonal time scales (Webster et al., 1998; Annamalai et al., 1999; Sperber et al., 2000; Krishnamurthy and Shukla, 2000; Goswami and Ajaya Mohan, 2001). However, little previous research has examined the structure of PV anomalies in the Somali Jet and their relation to monsoon rainfall over India. In our study, we focus on assessing the relationships between PV 
anomalies in the Somali Jet near the equator and rainfall during active and break phases of the Indian monsoon during the July and August season.

The remainder of this paper is organized as follows. Section 2 contains details of the datasets used and methodology followed. Section 3 discusses results of our analysis of the monsoon dynamics during active and break phases, along with evolution of Somali Jet PV during these phases. Conclusions are presented in Section 4.

\section{Data and Methodology}

We use the daily $0.5^{\circ}$ resolution rainfall gridded dataset developed by the Indian Meteorological Department (IMD) for the months of July and August. The reason for not including June and September in the present study is because during those months, ISM signals are likely to be contaminated by the onset and withdrawal phases of the monsoon, respectively. The dataset is well validated and reliable (Rajeevan and Bhate, 2008) and available from 1971 to 2005 with a domain starting at $6.5^{\circ} \mathrm{N}, 66.5^{\circ} \mathrm{E}$ (as the south-west corner) over a total of $69 \times 65$ grid points. As a proxy for large-scale convection of tropical regions we use the interpolated Outgoing Longwave Radiation (OLR) data of Liebmann and Smith (1996) obtained from NOAA/OAR/ESRL PSD, Boulder, Colorado from http://www.esrl.noaa.gov/psd on a $2.5^{\circ} \mathrm{x}$ $2.5^{\circ}$ global grid.

Global atmospheric and surface fields are extracted from the European Centre for Medium Range Weather Forecasts (ECMWF) Interim Re-Analysis data (Dee et al., 2011; ERA-Interim hereafter) from 1979 to 2005. ERA-Interim operates at a spectral T255 horizontal resolution corresponding to approximately $79 \mathrm{~km}$ spacing on a reduced Gaussian grid at 6-hourly time means and on 60 vertical levels, with the model top at $0.1 \mathrm{hPa}$ (about $64 \mathrm{~km}$ ). Data used in the atmosphere are: $\mathrm{PV}$ at $850 \mathrm{hPa}$, zonal and meridional wind components ( $\mathrm{u}$ and v), air 
temperature (T), vertical velocity $(\omega)$, specific humidity (q) and geopotential height (z) at the 1000-, 925-, 850-, 700-, 600, 500-, 400-, and 300-hPa pressure levels. The study period chosen is based on the availability of corresponding IMD rainfall observations at $0.5^{\circ} \times 0.5^{\circ}$ resolution, which is limited to the period 1979-2005 (Rajeevan and Bhate, 2008). Climatological means and anomalies are estimated for each of the selected variables from the reanalysis data for the peak monsoon season (JA) and the anomalies plotted for all the selected variables are relative to the climatology for July-August for the period 1979-2005.

To understand the dynamics of the Somali Jet, PV anomalies and associated variables at $850 \mathrm{hPa}$ have been plotted over the region $0^{\circ} \mathrm{N}-25^{\circ} \mathrm{N}, 45^{\circ} \mathrm{E}-80^{\circ} \mathrm{E}$, shown in Fig. 1 (Box-1) during active and break spells of the monsoon. Based on the spatial structure of Somali Jet PV anomalies over Box-1, this region has been selected for further discussion of Somali Jet PV dynamics because it is representative of PV transport and associated convection.

The potential vorticity equation as mentioned in Rodwell and Hoskins (1995) can be written as: $\frac{D P}{D t}=\frac{1}{\rho} F_{\zeta} \cdot \nabla \theta+\frac{1}{\rho} \zeta \cdot \nabla \dot{\theta}$,

where $\mathrm{P}$ is potential vorticity, $\nabla$ is $3 \mathrm{D}$ gradient operator, $F_{\zeta}=\nabla \times F_{v}$, (the $3 \mathrm{D}$ curl of momentum forcing) and $\dot{\theta}=D \theta / D t$. The two terms on the right-hand side of the PV equation represent the material modification to PV due to frictional and diabatic effects respectively.

\subsection{Defining active and break phases}

To obtain the dates of active and break events we use an index over the Monsoon Core Region (hereafter MCR; $73^{\circ} \mathrm{E}-82^{\circ} \mathrm{E}$ and $18^{\circ}-28^{\circ} \mathrm{N}$ as in Mandke et al., 2007). For preparing the daily rainfall time series from IMD data over MCR, area averaging has been performed for JA over the period 1979-2005. For the calculation of the daily-standardized anomaly rainfall time series, the daily precipitation anomaly to the climatological seasonal cycle is divided by the daily- 
evolving standard deviation of the time series. Based on this standardized anomaly time series, active (break) spells are distinguished as periods when the value of the standardized anomaly for the rainfall is greater than +1 (less than -1$)$ standard deviation for at least three consecutive days. The corresponding dates (as listed in Table 1) are then used to select corresponding active and break phases from ERA-Interim and other datasets over the 1979-2005 period. The method used is similar to that in Rajeevan et al. (2006). Some of the active and break spell dates of this study during JA do not coincide with observations in some previous studies in some of the years but they compare well to the dates given by Maharana and Dimri (2015). This slight mismatch in the dates can be attributed to length of study period chosen: since rainfall is considered over the MCR for JA only, some events are missed at the June-July and July-August boundaries.

\subsection{Diabatic heating}

The thermodynamic energy equation presented in Newell et al. (1974), in pressure coordinates, is used for the calculation of the diabatic heating term:

$$
\frac{\partial \bar{T}}{\partial t}+\frac{1}{a}\left(\frac{\bar{u}}{\cos \phi} \frac{\partial \bar{T}}{\partial \lambda}+\bar{v} \frac{\partial \bar{T}}{\partial \phi}\right)+\bar{\omega}\left(\frac{\partial \bar{T}}{\partial p}-\frac{R \bar{T}}{c_{p} p}\right)=\overline{\dot{Q}}
$$

where $c p$ is the specific heat of dry air at levels of constant pressure, $R$ is the gas constant for dry air, and $p$ is the pressure. The heating term $\dot{Q}$ includes contributions by the transfer of heat by turbulent and molecular conduction $\dot{Q}_{\mathrm{s}}$, from latent heat release $\dot{Q}_{1}$, and by radiative processes $\dot{Q}$ r. Diabatic heating rate fields are computed from the above equation as a residual, using daily data from ERA-Interim. The quantities with bars above indicate time averages.

\section{Results}

Lagged composites of different meteorological parameters have been studied here in order to understand how different processes and signals change and propagate during mean active and break phases. These composites have been generated using the standardized rainfall anomaly in 
the MCR region as described in Section 2.1, with lags over the range \pm 10 days. A composite of original dates of active and break spells calculated for JA months from the period 1979-2005 is chosen as lag00. Other lag dates are calculated with respect to the peak day (for example, if the peak (lag=0) date is $20^{\text {th }} \mathrm{July}$, then the lag+02 date is $22^{\text {nd }} \mathrm{July}$, etc.).

Lagged composites of daily rainfall anomalies over the whole Indian landmass are shown in Fig. $2 \mathrm{a}$ and $\mathrm{b}$ for active and break phases respectively. Fig. $2 \mathrm{a}$ shows the movement of a band of positive rainfall anomalies from southern India to the monsoon core zone, i.e. generally northwards, over the development of the active event, i.e. from lag-10 to lag00. Shortly after the peak, negative rainfall anomalies exist over the foothills of the Himalayas and the southeast peninsula region, the latter being a rain shadow region, receiving reduced rainfall in the lee of the Western Ghats mountains. The period from lag-02 to lag+02 also shows the propagation of very large positive rainfall anomalies from the east coast adjoining the Bay of Bengal $(\mathrm{BoB})$ towards the northwest, suggestive of moving anomalies up the monsoon trough. The lagged composites during the break phase (Fig. 2b) show a general reversal of the rainfall anomalies compared to active phases, with negative rainfall anomalies over the Western Ghats, and general northward propagation of negative anomalies from the western part of central India at lag-08, covering the whole central region by lag-04 and with more intense anomalies by lag00. The evolution of rainfall during active and break phases of the monsoon is discussed in more detail by Krishnamurthy and Shukla (2000, 2007, 2008), Rajeevan and Bhate (2008) and Maharana and Dimri (2016).

Rainfall over India is supported largely via the transport of moisture from the Arabian Sea and southern Indian Ocean by the strong cross-equatorial Somali Jet winds (Findlater, 1969; Naidu et al., 2011a). On interannual and intraseasonal timescales, variations in SST in the tropical Indian 
Ocean are also known to be strongly affected by monsoon wind variability (McCreary et al., 1993; Sengupta et al., 2001; Ramesh and Krishnan, 2005). Lagged composites of wind anomalies at $850 \mathrm{hPa}$ during active and break periods are presented in Fig. 3a, b respectively. The lagged composite of wind-speed anomalies during active spells (Fig. 3a) shows a negative anomaly over northern India that moves northwards as time continues towards lag00. Conversely, during break periods (Fig. 3b), exactly the opposite pattern is observed, i.e. weaker westerlies during lag-04 to lag+02 and negative wind anomalies over the MCR region and Arabian Sea.

The PV budget calculation by Rodwell and Hoskins (1995) demonstrated how the change in sign in Coriolis parameter at the equator prevents cross-equatorial flow in the absence of material tendencies in PV. They showed that the frictional torque exerted by the East African Highlands on the Somali Jet is an important mechanism for modifying PV. According to Rodwell and Hoskins (1995), when there is very little further modification of the PV, the Somali Jet turns anticyclonically over the Arabian Sea and the flow tends to avoid India. Lagged composites of PV during active and break periods (figure not shown) over the Arabian Sea at $850 \mathrm{hPa}$ have been plotted in order to show the spatial pattern of PV advection during these periods which display advection of negative PV across the equator into the Northern Hemisphere over the western Indian Ocean. While there are many similarities between active and break phases, the periods immediately before the peak active phase, and 6 days after the peak break, do display more negative PV anomalies upstream over the western equatorial Indian Ocean.

The PV anomalies themselves are shown in Figs. $4 \mathrm{a}$ and $4 \mathrm{~b}$ for active and break periods respectively. The regions in Figs $4 \mathrm{a}$ and $4 \mathrm{~b}$ have been selected in order to get an overview of PV behavior over the whole Arabian Sea rather than just over the SW region. During active spells, a 
negative PV anomaly exists in the south-eastern quadrant of the Arabian Sea, consistent with a lack of material modification of PV, which is then manifested by a stronger Somali Jet that curves to the east over southern India (See Fig. 3a). This negative PV anomaly weakens after

251 lag00. During break periods (Fig. 4b), the opposite pattern exists: positive PV anomalies in the south eastern region of the Arabian Sea imply greater modification of PV by diabatic mechanisms, and weaker westerly winds over southern India (see Fig. 3b); the positive PV anomaly gets stronger from lag-10 to lag00, before becoming weaker as time moves past the peak of the break period.

In order to examine the vertical structure of the PV anomalies, they are shown at the $500 \mathrm{hPa}$ level in Fig. 5a and 5b. During active periods (Fig. 5a), negative PV anomalies mostly cover the central and western Arabian Sea at lag00, before dissipating in time by lag+10. During break periods (Fig. 5b), the converse is true: modified, i.e. positive, PV anomalies occur over the Arabian Sea region which again dissipate by lag +10 .

The concept of PV has been found particularly helpful by Hoskins et al (1985) to analyze the role of diabatic processes in the development of PV anomalies. In order to explain the material modification in Somali Jet PV, we have examined daily diabatic heating anomalies at $850 \mathrm{hPa}$ for lag-10 to +10 in active and break periods; the results are shown in Fig. $6 \mathrm{a}$ and $6 \mathrm{~b}$ respectively. During active periods (Fig. 6a), negative diabatic heating anomalies build over the southern Arabian Sea, indicating less convection (and hence less PV modification) from lag-06 to lag+06. During break events (Fig. 6b), there is an east-west split in the southern Arabian Sea, with the eastern half covered by negative diabatic heating anomalies between lag-10 to lag00, which dissipate by lag +10 . 
The large-scale pattern of convection has been shown in order to understand the thermodynamic state of atmosphere and its variability during the modification of PV that prevails in different phases of monsoonal season using outgoing longwave radiation (OLR, contour) and lagged composites of SST (shaded) anomalies for active and break spells is shown in Fig. 7a and b respectively between lag-10 to +10 . During an active spell (Fig. 7 a, contour) a strong negative OLR anomaly covers most of the Arabian Sea region and Western Ghats, consistent with enhanced deep cloud cover, while a positive anomaly can be seen south of the Indian peninsula, which slowly moves northwards as time progresses. Between lag+02 and lag +10 , positive anomalies grow over most of the Arabian Sea region especially between lag+08 and lag+10. The NW-SE split in OLR anomalies mirrors the shape of PV anomalies, such that in the SE quadrant of the Arabian Sea, positive OLR anomalies developing following an active phase imply reduced convection, less mixing in the atmospheric $\mathrm{BL}$, a shoaling of the atmospheric $\mathrm{BL}$, and less material modification of PV; this results in the negative PV anomalies displayed in the positive lags of Fig. 4a, and the anticyclonic curvature of winds over the south of India. Since break phases develop following the transition from active periods, breaks (Fig. 7b, contour) are characterized by the presence of strong positive OLR anomalies that completely cover the Somali Jet PV region from lag-08 to lag-02, but then move northwards as time progresses. The break periods suggest more modification of PV by convection and boundary layer mixing, and a deeper mixing in the atmospheric BL leading to deepening of the atmospheric BL over the northern Arabian Sea, which is consistent with winds curving weakly i.e. weaker south westerlies over the northern half of India (See Fig. 3b).

For SST anomalies, during active periods, the NW/SE split is again apparent, with a band of anomalously cold SSTs that moves slowly northwestwards from lag-10 to+10, removing the 
warm SST anomaly in the northern Arabian Sea during lags-10 to lag-04. The presence of colder SSTs is because of enhanced upwelling of relatively cold subsurface oceanic water by windstress curl anomalies (see later). The cold anomalies appear to slightly lead the similar northwestward movement of warm OLR anomalies (See Fig. 7a, shaded), which is consistent with colder SSTs inhibiting convection and increasing OLR. During the break periods (Fig. 7b, shaded), weaker winds cause less upwelling, and warm SST anomalies slowly move northwards across the Arabian Sea from lag-06 to lag+06. The north-south dipole seen during both active and break periods is hereafter referred as the Arabian Sea Dipole (ASD), and is similar to other dipoles observed both in the Arabian Sea and the Bay of Bengal during active and break phases (Krishnan et al., 2000).

The spatial structure of wind stress is important in understanding how wind forcing affects ocean upwelling, and the consequent effects on SST. Lagged composites of anomalies of wind stress and their curl are plotted in Fig. 8. The anomalies display a similar pattern to the winds shown in Fig. 3. During active phases, strong positive wind stress curl anomalies force oceanic upwelling and cooling on the northern/northwestern flank of the Somali Jet up to lag+02, while a negative windstress curl pattern builds on the southern/southeastern flank of the Somali Jet from lags-06 to+02, which tends to reduce upwelling and raise SST. These patterns are consistent with the cold SST anomalies displayed in Fig. 7a (shaded) that are slowly shunted northwestwards. During break periods (Fig. 8b), a similar but opposite pattern of wind stress curl and wind stress is observed; positive wind stress curl on the southern/southeastern flank from lag-04 to lag+04, and negative wind stress curl on the northern/northwestern flank. These patterns of wind stress curl and wind stress during active and break periods are in agreement with the results of Anderson et al. (1992). 
As an example, the lagged correlations between PV versus SST and PV versus rainfall are shown in Fig. 9. The correlation between PV and SST shows a high positive correlation at lag-04 which indicates the lagging of PV by SST on a scale of 4 days while a maximum negative correlation between PV and rainfall can be seen at lag00.

\section{Discussion and Conclusions}

The above results suggest a potential feedback loop that connects various aspects of intraseasonal monsoon core region (MCR) rainfall and offer a mechanism for the propagation of related anomalies. Key to the feedback is the northwest/southeast split in PV anomaly and windstress curl in the Arabian Sea. A schematic of such a feedback for active and break phases is shown in Fig. 10, and described here.

If one considers an active period anomaly over the south eastern Arabian Sea, an oceanic Rossby wave for instance might cause a negative SST anomaly (Fig. 7a, shaded) lag-08 to -04). The Somali Jet in this region has a negative PV anomaly in its southern flank and a positive PV anomaly on its northern flank (Fig. 4a lag-08 to 00). This negative SST anomaly will be associated with reduced evaporation, less convection and higher OLR (Fig. 7a, contour) lag-08 to -04), which leads to less mixing of PV. The negative PV anomaly acts to curve the flow anticyclonically, causing a negative (downwelling) windstress curl anomaly on the jet's southern flank (Fig. 8a lag-06 to +02), and thus surface warming there. Conversely the positive PV anomaly on the jet's northern flank acts to curve the flow cyclonically, causing an upwelling windstress curl, and a surface cooling north of the jet. Because the mixed layer is deeper towards the south of the jet, the overall effect is to cool the northern Arabian Sea more quickly than the southern Arabian Sea warms (Fig. 7a, shaded) lag00 to +10). 
On the other hand, if one considers a break period anomaly, a positive SST anomaly (Fig 7b, shaded) lag-08 to -04) leads to more evaporation, more convection and lower OLR over the southern Arabian Sea (Fig. 7b, contours) lag-04 to +02 ), which leads to more mixing of PV: The Somali Jet in this region then has a positive PV anomaly on its southern flank and a negative PV anomaly on its northern flank (Fig. $4 \mathrm{~b}$ lag-04 to +02 ). The positive PV anomaly acts to curve the flow cyclonically, causing a positive (upwelling) windstress curl anomaly on the jet's southern flank (Fig. 8b lag-04 to +04), and surface cooling south of the Jet. Again, because the mixed layer is deeper towards the south of the jet, the overall effect is to warm the northern Arabian Sea faster than the southern Arabian Sea cools (Fig. 7b, shaded) lag00 to +10).

The descriptions above deal with the onset of the anomalous winds, but not the timescale over which the wind anomalies decay: this happens after lag+02 for active events, and after lag+06 for break events. For active events, the slow warming developing over the southern Arabian Sea (Fig. 7a, shaded) lag+02 to +10 ) allows more evaporation, convection, mixing and PV modification, reducing the negative PV anomaly (Fig 4a lag+04 to +10 ); the opposite (cooling and reduction of positive PV anomalies) happens following break events. Additionally, during active events, high vertical wind shear in the BL might itself cause large amounts of mixing and PV modification. Consideration of PV anomalies therefore allows a mechanism whereby SST anomalies build and propagate northwestwards through the Arabian Sea during active and break periods.

The timescale for the feedback is essentially set by the timescales for anomalies in diabatic forcing to change Somali Jet PV, and for resulting wind stress curl anomalies to force vertical ocean velocities in the mixed layer that significantly change SST. It can be estimated in a similar manner to Marshall et al. (2001) and O'Callaghan et al. (2014) by expressing the Ekman-induced 
transport as a pseudo heat flux $H_{E}=c_{p} \Delta S S T \nabla \times \tau / f$, where $\Delta S S T$ is the horizontal SST gradient across the domain (or $\sim 2 \mathrm{~K}$ ), $c_{p}$ is the specific heat capacity of water, $\nabla \times \tau$ is estimated from Fig. 8 , and $f \approx 2 \times 10^{-5} \mathrm{~s}^{-1}$. The temperature change of the surface can then be calculated assuming that the heat flux is distributed throughout the mixed layer, which we assume is $40 \mathrm{~m}$ deep. Following the peak of an active event, $H_{E} \approx 20 \mathrm{Wm}^{-2}$, implying a change in temperature of $\mathrm{O}(0.1) \mathrm{K}$ (the size of the anomalies that emerge in the south eastern corner of the panels in Fig. 7 (shaded)) over 10 days.

While the precise role of PV anomalies in the Somali Jet on the intensity and structure of different phases of ISM rainfall is debated, it has been broadly acknowledged in previous studies that modification in PV is required in order to avoid breaks in the monsoon (Rodwell and Hoskins, 1995; Rodwell, 1997; Joseph and Sijikumar, 2004). Our work suggests a more complex picture of PV whereby during an active event, PV modification (from negative to positive) is minimal over the Arabian Sea, but mainly happens as the flow crosses the peninsula and turns cyclonically northward, causing a low pressure anomaly. Conversely, during a break, PV is being significantly modified upstream over the Arabian Sea, weakening the jet and reducing flow onto the Indian peninsula: the result is an absence of convergence over India, and a lack of rainfall.

Simulating ISM variability therefore requires coupled ocean-atmosphere GCMs that represent the above feedbacks correctly, such as the oceanic mixed layer response to a wind stress curl anomaly, and convection and subsequent PV modification response to an SST anomaly. If feedbacks such as these are weak in GCMs, then ISM variability may be too weak; conversely, if such feedbacks are too strong, ISM variability may be so strong that mean rainfall can be significantly biased. We therefore speculate that adequate vertical resolution of the upper ocean 
is necessary in order to resolve PV-driven interactions with the oceanic mixed layer. In addition, since key elements of these feedbacks such as ocean mixed layer processes and convection are parametrized, we suggest that analysis of such feedbacks in a variety of coupled oceanatmosphere GCMs should be performed in future.

Climate model projections of the ISM later in this century suggest increased mean rainfall, but greater variability (e.g. as reviewed in Turner and Annamalai, 2012). Warmer SSTs suggest shallower ocean mixed layers (though the dynamical influence of ISM winds on the ocean is important over the Arabian Sea), and potentially a different relationship between convection and the response of PV modification to an SST anomaly, e.g. due to changed humidity and lapse rates. Analysis of how GCMs simulate present-day PV behavior in different phases of the ISM may therefore shed light on understanding ISM variability in different GCM projections of $21^{\text {st }}$ century climate change.

In the present study, we have examined the variability of rainfall on intraseasonal time scales and atmospheric processes associated with it over the monsoon core region (MCR; as a representative region of Indian monsoon variability) and its relation with PV anomalies in the Somali Jet during different phases of the ISM. By shedding light on the response of the ISM to modified PV, and resulting flow - precipitation interactions, this study will contribute to better understanding the influence of Somali Jet dynamics on the monsoon on different time scales.

\section{Acknowledgements}

The first author acknowledges Council of Scientific and Industrial Research (CSIR) funding for Junior Research Fellowship. A. G. Turner is supported in this work by the core grant to the National Centre for Atmospheric Science and as part of the NERC-funded INCOMPASS project NE/L01386X/1. 


\section{References}

Anderson, D. M., and Prell, W. L. (1992). The structure of the southwest monsoon winds over the Arabian Sea during the late Quaternary: Observations, simulations, and marine geologic evidence. Journal of Geophysical Research: Oceans, 97(C10), 15481-15487.

Anderson, D. M., Brock, J. C., and Prell, W. L. (1992). Physical upwelling processes, upper ocean environment and the sediment record of the southwest monsoon. Geological Society, London, Special Publications, 64(1), 121-129.

Annamalai, H., Slingo, J. M., Sperber, K. R., and Hodges, K. (1999). The mean evolution and variability of the Asian summer monsoon: Comparison of ECMWF and NCEP-NCAR reanalyses. Monthly Weather Review, 127(6), 1157-1186.

Bhat G.S. (2001). Near surface atmospheric characteristics over the North Bay of Bengal during the Indian Summer Monsoon. Geophysical Research Letters, 28:987-90.

Dee, D. P., Uppala, S. M., Simmons, A. J., Berrisford, P., Poli, P., Kobayashi, S., ... and Bechtold, P. (2011). The ERA-Interim reanalysis: Configuration and performance of the data assimilation system. Quarterly Journal of the royal meteorological society, 137(656), 553-597.

Findlater, J. (1969). A major low-level air current near the Indian Ocean during the northern summer. Quarterly Journal of the Royal Meteorological Society, 95(404), 362-380.

Findlater, J. (1971). Mean monthly airflow at low levels over the western Indian Ocean (No. 116). HM Stationery Office.

Findlater, J. (1977). Observational aspects of the low-level cross-equatorial jet stream of the western Indian Ocean. Pure and Applied Geophysics, 115(5-6), 1251-1262.

Goswami BN. (2005). South Asian monsoon. In Intraseasonal Variability in the AtmosphereOcean Climate System, ed. WKM Lau, DE Waliser, pp. 19-61. Berlin: Praxis Springer. Goswami, B. N., Ajayamohan, R. S., Xavier, P. K., and Sengupta, D. (2003). Clustering of 
synoptic activity by Indian summer monsoon intraseasonal oscillations. Geophysical Research Letters, 30(8).

Goswami, B. N., and Ajayamohan, R. S. (2001). Intraseasonal oscillations and interannual variability of the Indian summer monsoon. Journal of Climate, 14, 1180-1198.

Hart, J. E., Rao, G. V., Van De Boogaard, H., Young, J. A., and Findlater, J. (1978). Aerial observations of the East African low-level jet stream. Monthly Weather Review, 106(12), 17141724.

Hoskins, B. J., McIntyre, M. E., and Robertson, A. W. (1985). On the use and significance of isentropic potential vorticity maps. Quarterly Journal of the Royal Meteorological Society, 111(470), 877-946.

Hoskins, B. J., and Rodwell, M. J. (1995). A model of the Asian summer monsoon. Part I: The global scale. Journal of the Atmospheric Sciences, 52(9), 1329-1340.

Huang, N. E., Shen, Z., Long, S. R., Wu, M. C., Shih, H. H., Zheng, Q., ... and Liu, H. H. (1998, March). The empirical mode decomposition and the Hilbert spectrum for nonlinear and nonstationary time series analysis. In Proceedings of the Royal Society of London A: Mathematical, Physical and Engineering Sciences (Vol. 454, No. 1971, pp. 903-995). The Royal Society.

Izumo, T., Montégut, C. B., Luo, J. J., Behera, S. K., Masson, S., and Yamagata, T. (2008). The role of the western Arabian Sea upwelling in Indian monsoon rainfall variability. Journal of Climate, 21(21), 5603-5623.

Jayakumar, A., Turner, A. G., Johnson, S. J., Rajagopal, E. N., Mohandas, S. and Mitra, A. K. (2016). Boreal summer sub-seasonal variability of the South Asian monsoon in the Met Office GloSea5 initialized coupled model. Climate Dynamics, published online, doi:10.1007/s00382016-3423-x. 
473 Krishnamurti, T. N., Wong, V., Pan, H. L., Pasch, R., Molinari, J., and Ardanuy, P. (1983). A 474 three-dimensional planetary boundary layer model for the Somali jet. Journal of the Atmospheric 475 Sciences, 40(4), 894-908.

Joseph, P. V., and Sabin, T. P. (2008). An ocean-atmosphere interaction mechanism for the active break cycle of the Asian summer monsoon. Climate dynamics, 30(6), 553-566. Joseph, P. V., and Sijikumar, S. (2004). Intraseasonal variability of the low-level jet stream of the Asian summer monsoon. Journal of Climate, 17(7), 1449-1458.

Joseph, P. V., Eischeid, J. K., and Pyle, R. J. (1994). Interannual variability of the onset of the Indian summer monsoon and its association with atmospheric features, El Nino, and sea surface temperature anomalies. Journal of Climate, 7(1), 81-105.

Krishnamurthy, V., and Shukla, J. (2000). Intraseasonal and interannual variability of rainfall over India. Journal of Climate, 13(24), 4366-4377.

Krishnamurthy, V., and Shukla, J. (2007). Intraseasonal and seasonally persisting patterns of Indian monsoon rainfall. Journal of climate, 20(1), 3-20.

Krishnamurthy, V., and Shukla, J. (2008). Seasonal persistence and propagation of intraseasonal patterns over the Indian monsoon region. Climate Dynamics, 30(4), 353-369.

Krishnamurti, T. N., and Ramanathan, Y. (1982). Sensitivity of the monsoon onset to differential heating. Journal of the Atmospheric Sciences, 39(6), 1290-1306.

Krishnamurti, T. N., and Wong, V. (1979). A planetary boundary-layer model for the Somali Jet. Journal of the Atmospheric Sciences, 36(10), 1895-1907.

Krishnamurti, T. N., Molinari, J., and Pan, H. L. (1976). Numerical simulation of the Somali jet. Journal of the Atmospheric Sciences, 33(12), 2350-2362. 
Krishnan, R., Zhang, C., and Sugi, M. (2000). Dynamics of breaks in the Indian summer monsoon. Journal of the Atmospheric Sciences, 57(9), 1354-1372.

Liebmann, B. (1996). Description of a complete (interpolated) outgoing longwave radiation dataset. Bulletin of the American Meteorological Society, 77, 1275-1277.

Maharana, P., and Dimri, A. P. (2016). Study of intraseasonal variability of Indian summer monsoon using a regional climate model. Climate Dynamics,46(3-4), 1043-1064.

Mandke, S. K., Sahai, A. K., Shinde, M. A., Joseph, S., and Chattopadhyay, R. (2007). Simulated changes in active/break spells during the Indian summer monsoon due to enhanced $\mathrm{CO} 2$ concentrations: assessment from selected coupled atmosphere-ocean global climate models. International journal of climatology, 27(7), 837-859.

Marshall J., Johnson, H. and Goodman J. (2001). A Study of the Interaction of the North Atlantic Oscillation with Ocean Circulation. Journal of Climate, 14, 1399-1421.

McCreary, J. P., Kundu, P. K., and Molinari, R. L. (1993). A numerical investigation of dynamics, thermodynamics and mixed-layer processes in the Indian Ocean. Progress in Oceanography, 31(3), 181-244.

Murakami, T., R. Godbole, and R. R. Kelkar, 1970: Numerical simulation of the monsoon along $80^{\circ}$ E. Proc. Conf. on the Summer Monsoon of South East Asia, Norfolk, VA, Navy Weather Research Facility, 39-51.

Murakami, T., Nakazawa, T., and He, J. (1984). On the 40-50 day oscillations during the 1979 Northern Hemisphere summer. I: Phase propagation. Journal of the Meteorological Society of Japan, 62(3), 440-468. 
Naidu, C. V., Krishna, K. M., Rao, S. R., Kumar, O. B., Durgalakshmi, K., and Ramakrishna, S. S. V. S. (2011). Variations of Indian summer monsoon rainfall induce the weakening of easterly jet stream in the warming environment? Global and Planetary Change, 75(1), 21-30.

Newell, R. E., Kidson, J. W., Vincent, D. G., and Boer, G. J. (1974). General circulation of the tropical atmosphere and interactions with extratropical latitudes. Volume 2 (No. COO-2195-16). Massachusetts Institute of Technology Press, Cambridge, MA.

O’Callaghan, A., Joshi, M., Stevens, D. and Mitchell, D. (2014). The effects of different sudden stratospheric warming types on the ocean. Geophysical Research Letters, 41, DOI: 10.1002/2014GL062179.

Premkumar, K., Ravichandran, M., Kalsi, S. R., Sengupta, D., and Gadgil, S. (2000). First results from a new observational system over the Indian seas. Current Science, 78(3), 323-330.

Rajeevan, M., and Bhate, J. (2009). A high resolution daily gridded rainfall dataset (1971-2005) for mesoscale meteorological studies. Current Science, 96(4), 558-562.

Rajeevan, M., Bhate, J., Kale, J. D., and Lal, B. (2006). High resolution daily gridded rainfall data for the Indian region: Analysis of break and active monsoon spells. Current Science, 91(3), 296-306.

Rajeevan, M., Gadgil, S., and Bhate, J. (2010). Active and break spells of the Indian summer monsoon. Journal of earth system science, 119(3), 229-247.

Ramesh, K. V., and Krishnan, R. (2005). Coupling of mixed layer processes and thermocline variations in the Arabian Sea. Journal of Geophysical Research: Oceans, 110(C5).

Rodwell, M. J. (1997). Breaks in the Asian monsoon: The influence of Southern Hemisphere weather systems. Journal of the Atmospheric Sciences, 54(22), 2597-2611. 
Rodwell, M. J., and Hoskins, B. J. (1995). A model of the Asian summer monsoon. Part II:

520

521

522

523

524 Cross-equatorial flow and PV behavior. Journal of the Atmospheric Sciences, 52(9), 1341-1356. Sengupta, D., and Ravichandran, M. (2001). Oscillations of Bay of Bengal sea surface temperature during the 1998 summer monsoon. Geophysical Research Letters, 28(10), 20332036.

Shenoi, S. S. C., Shankar, D., and Shetye, S. R. (2002). Differences in heat budgets of the nearsurface Arabian Sea and Bay of Bengal: Implications for the summer monsoon. Journal of Geophysical Research: Oceans, 107(C6).

Shukla, J. (1987a). Interannual variability of monsoons, Monsoons. J. S. Fein, P. L. Stephens, 399-464, John Wiley and Sons.

Shukla, J., and Misra, B. M. (1977). Relationships between sea surface temperature and wind speed over the central Arabian Sea, and monsoon rainfall over India. Monthly Weather Review, 105(8), 998-1002.

Slingo, J., Spencer, H., Hoskins, B., Berrisford, P., and Black, E. (2005), The meteorology of the Western Indian Ocean, and the influence of the east African highlands. Philosophical Transactions of the Royal Society of London A, 363, 25-42.

Sperber, K. R., Slingo, J. M., and Annamalai, H. (2000). Predictability and the relationship between subseasonal and interannual variability during the Asian summer monsoon. Quarterly Journal of the Royal Meteorological Society,126(568), 2545-2574.

Turner, A. G. and Annamalai, H. (2012). Climate Change and the South Asian summer monsoon. Nature Climate Change, 2, 587-595.

Vecchi, G. A., and Harrison, D. E. (2002). Monsoon Breaks and Subseasonal Sea Surface Temperature Variability in the Bay of Bengal. Journal of Climate, 15(12), 1485-1493. 
543 (2011). Processes of 30-90 days' sea surface temperature variability in the northern Indian

544 Ocean during boreal summer. Climate Dynamics, 38(9-10): 1901-1916.

545 Webster, P. J., Magana, V. O., Palmer, T. N., Shukla, J., Tomas, R. A., Yanai, M. U., and 546 Yasunari, T. (1998). Monsoons: Processes, predictability, and the prospects for 547 prediction. Journal of Geophysical Research: Oceans, 103(C7), 14451-14510.

548 Wu, Z., and Huang, N. E. (2004). A study of the characteristics of white noise using the 549 empirical mode decomposition method. In Proceedings of the Royal Society of London A: 550 Mathematical, Physical and Engineering Sciences (Vol. 460, No. 2046, pp. 1597-1611). The 551 Royal Society.

552 Wu, Z., and Huang, N. E. (2009). Ensemble empirical mode decomposition: a noise-assisted data 553 analysis method. Advances in adaptive data analysis, 1(01), 1-41.

554 Xavier, P. K., Marzin, C., and Goswami, B. N. (2007). An objective definition of the Indian 555 summer monsoon season and a new perspective on the ENSO-monsoon relationship. Quarterly 556 Journal of the Royal Meteorological Society, 133(624), 749-764.

557 Yang, D. S., and Krishnamurti, T. N. (1981). Potential vorticity of monsoonal low-level 558 flows. Journal of the Atmospheric Sciences, 38(12), 2676-2695.

559 Zhang, J., Yan, R., Gao, R. X., and Feng, Z. (2010). Performance enhancement of ensemble 560 empirical mode decomposition. Mechanical Systems and Signal Processing, 24(7), 2104-2123. 


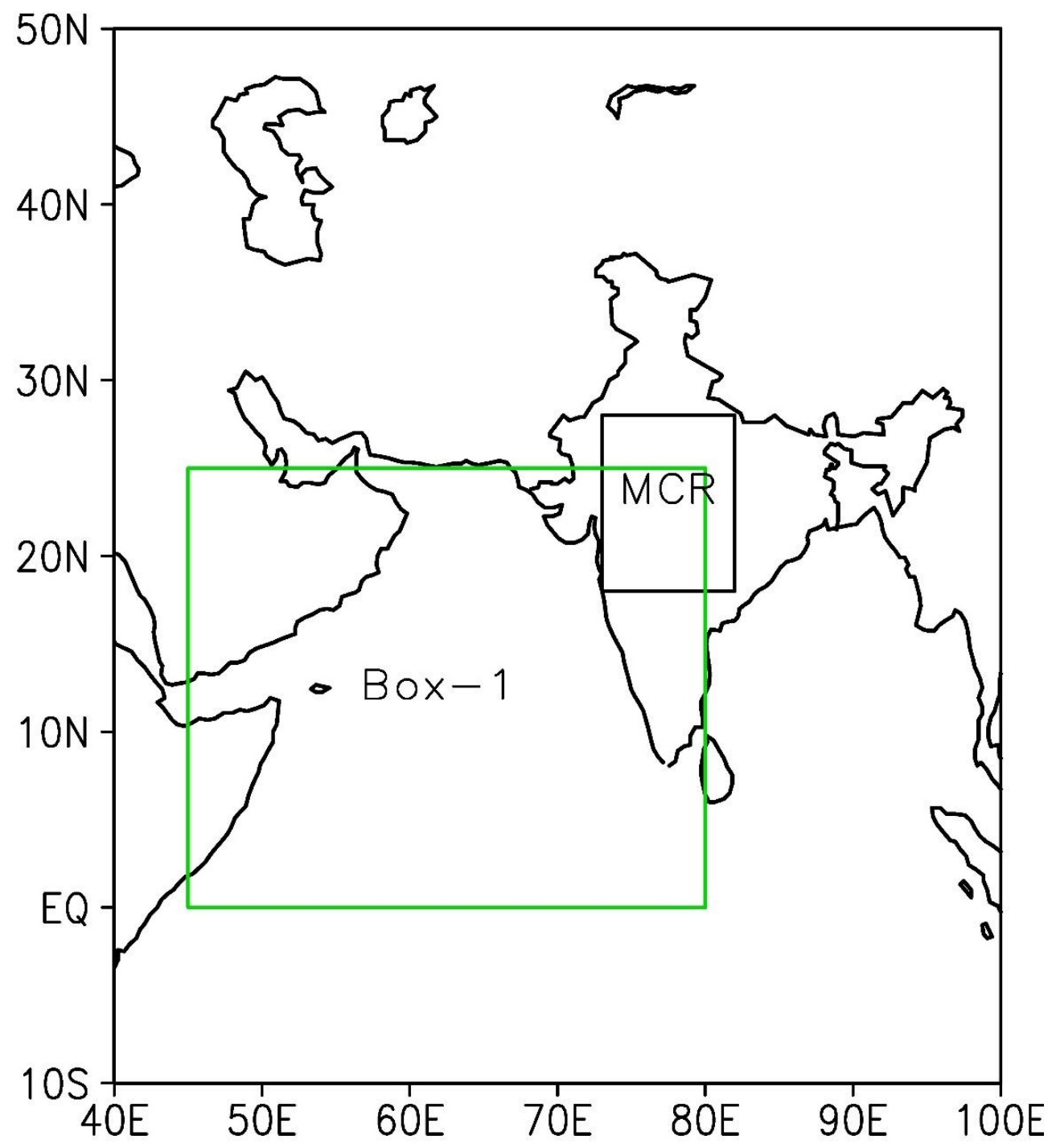

Fig.1. Study region considered over the Indian political boundary (hereafter referred to as 'India') and Indian monsoon core region $\left(73^{\circ} \mathrm{E}-82^{\circ} \mathrm{E}\right.$ and $18^{\circ} \mathrm{N}-28^{\circ} \mathrm{N}$; box-MCR) along with Somali Jet $\mathrm{PV}$ region $\left(45^{\circ} \mathrm{E}-80^{\circ} \mathrm{E}\right.$ and $0^{\circ} \mathrm{N}-25^{\circ} \mathrm{N}$; Box-1). 


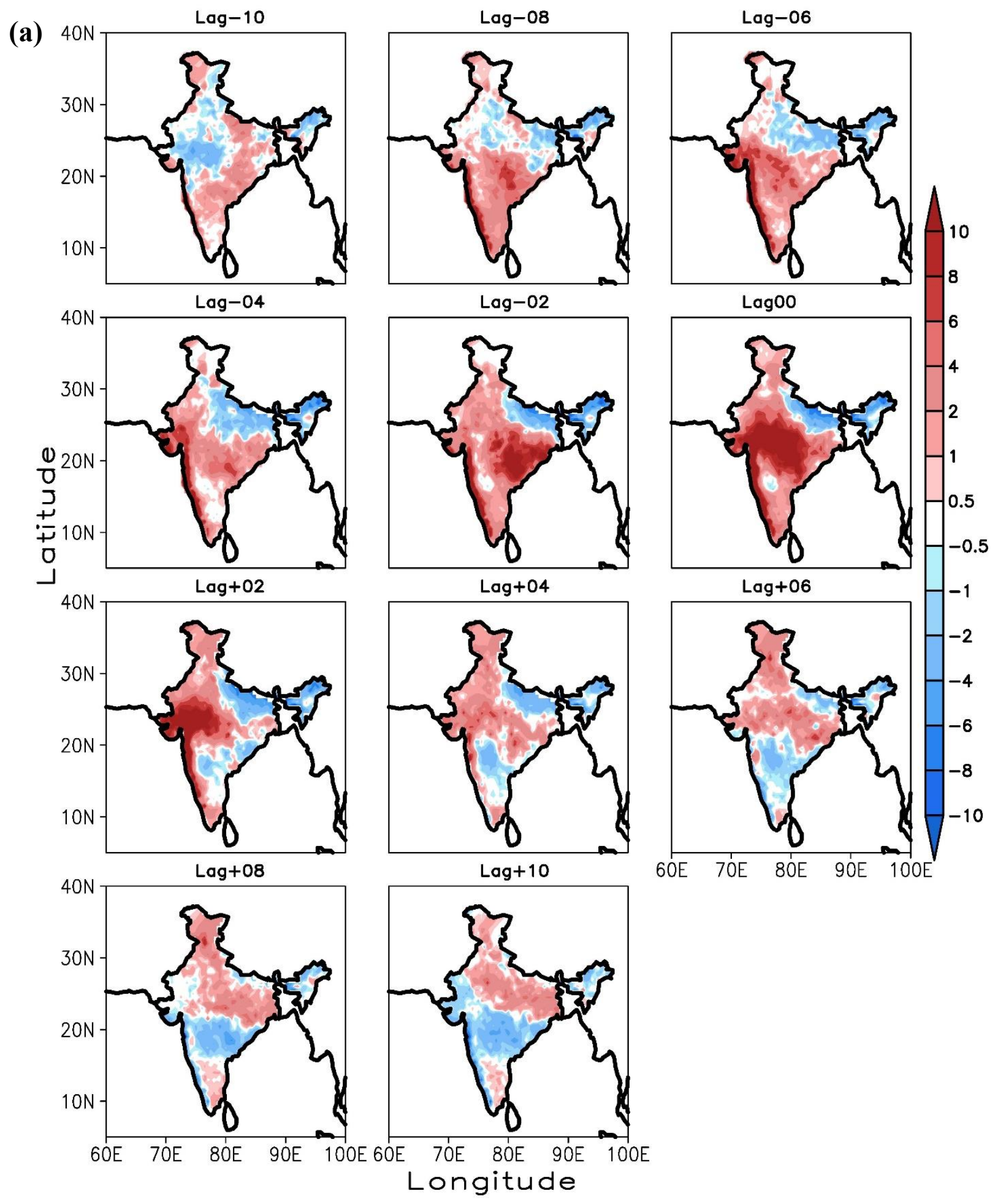


(b)
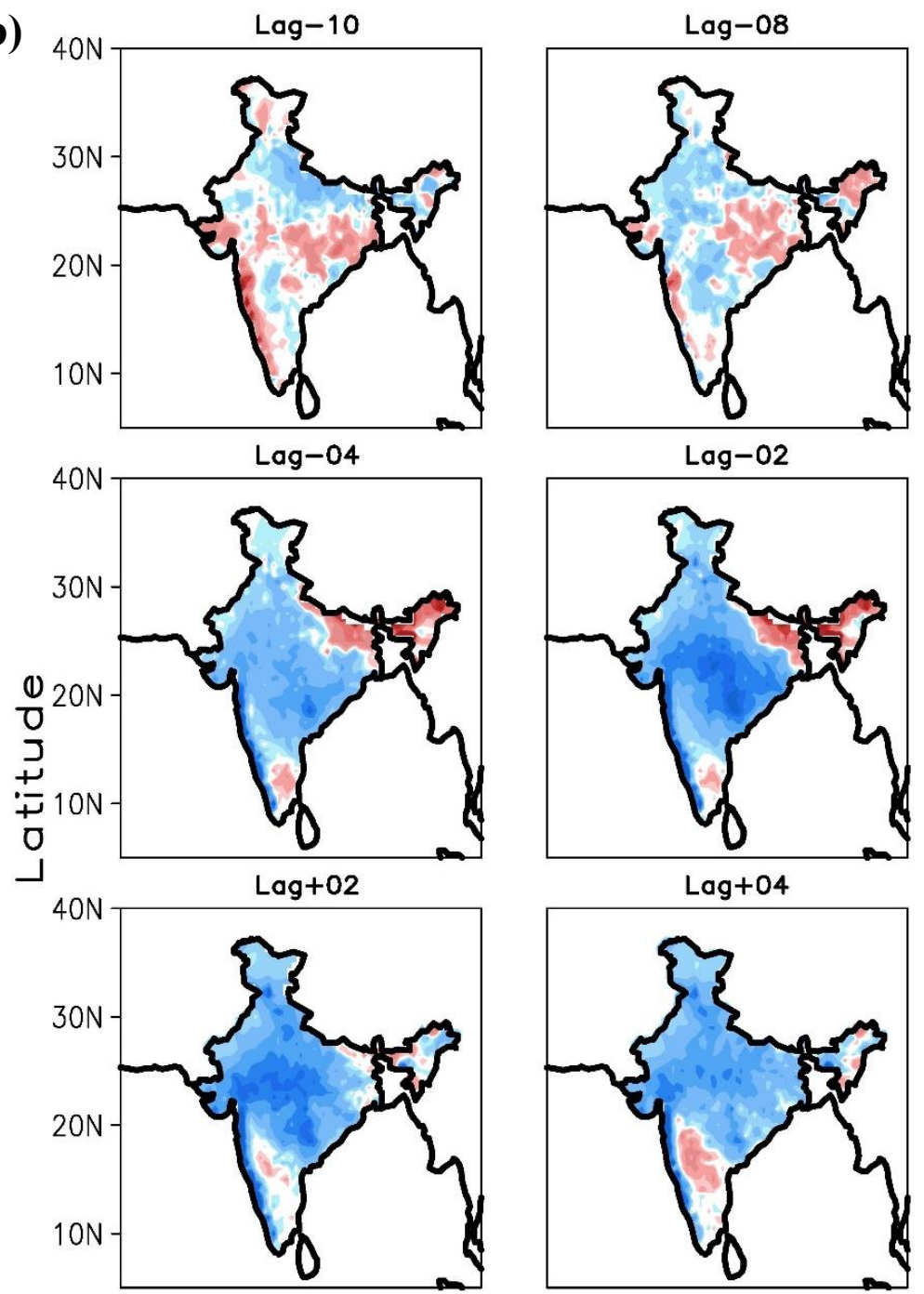

Lag+08
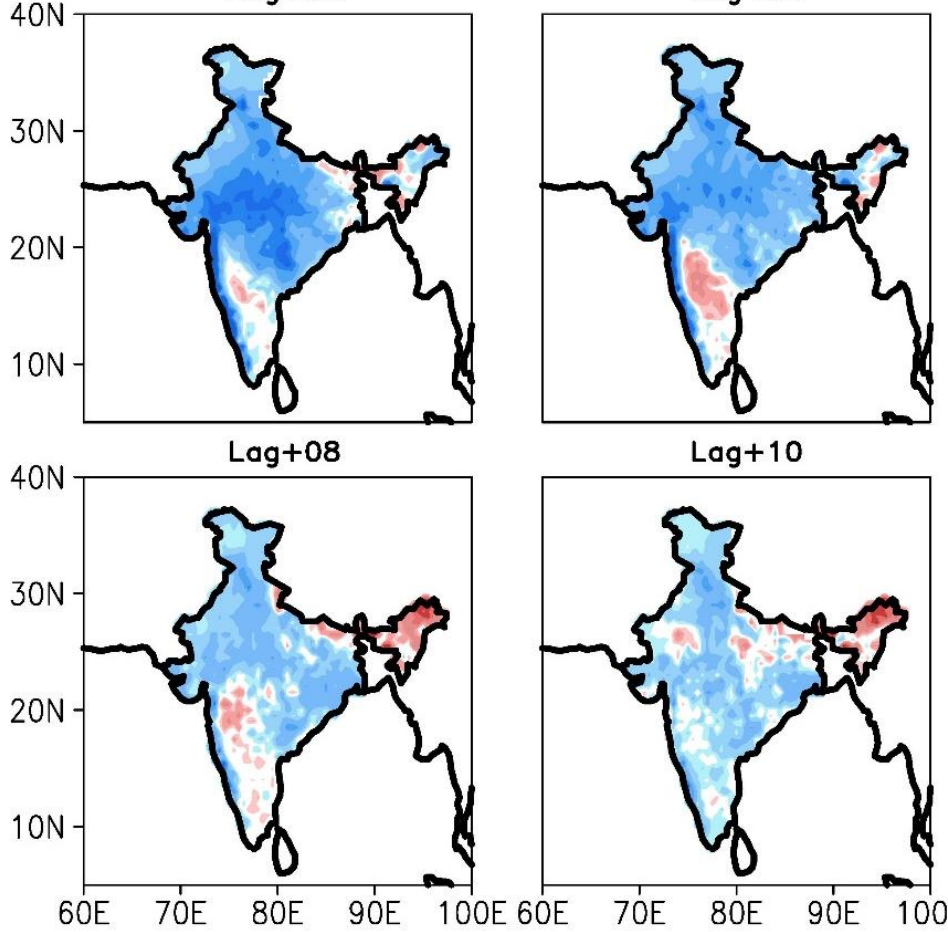

Lag+10
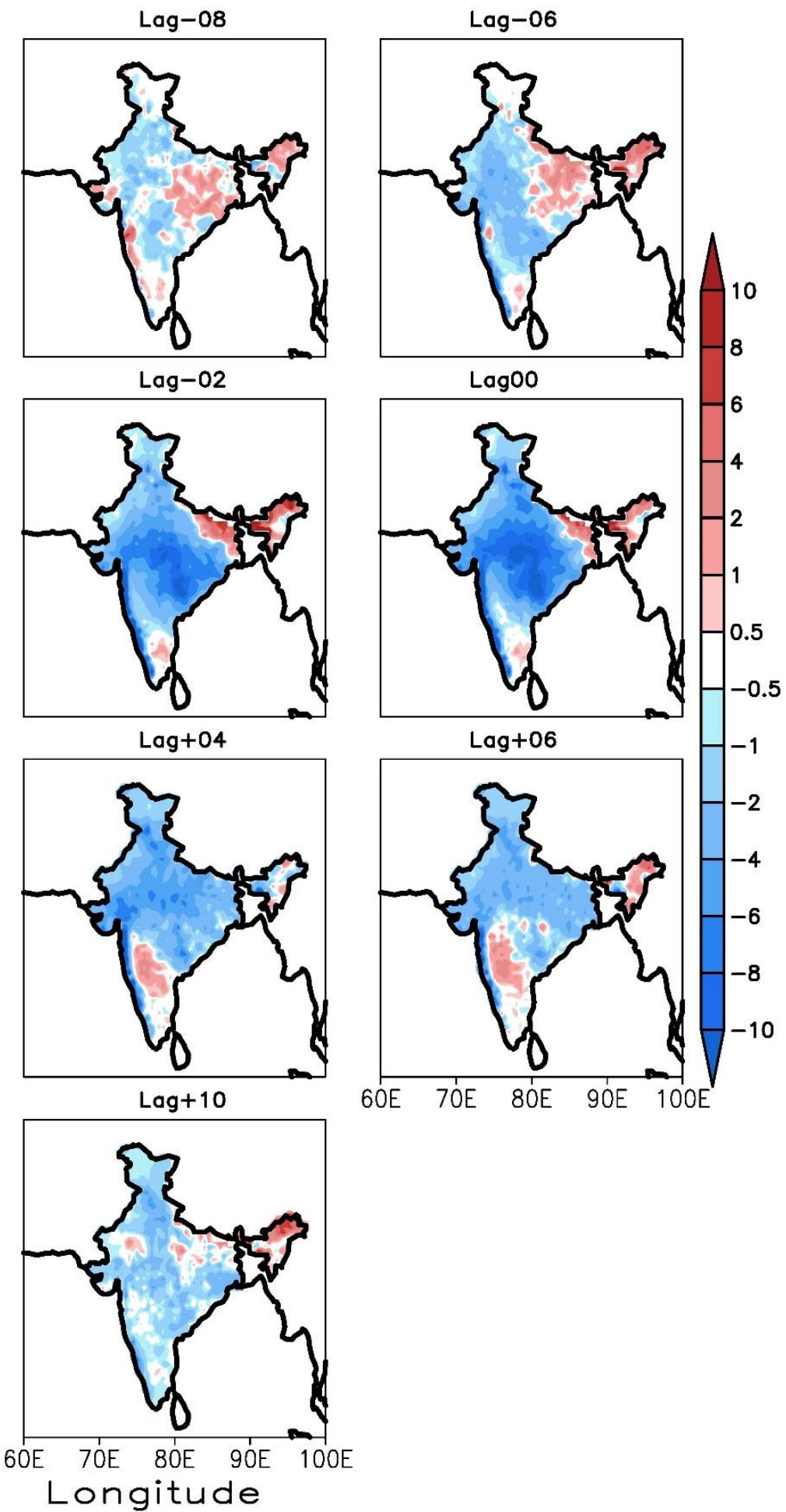

Fig. 2. Time-averaged lagged composite of daily rainfall (mm/day) anomalies from lag+10 to lag10 for (a) active, and (b) break periods. 
(a)

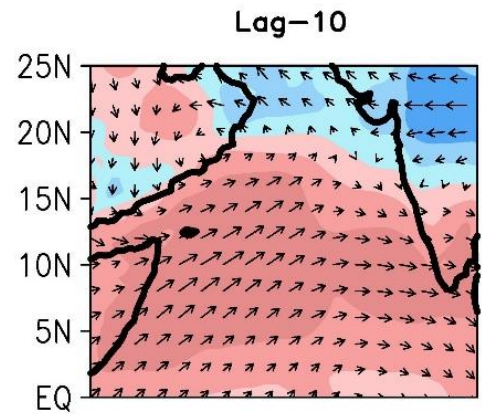

$$
\text { Lag-04 }
$$

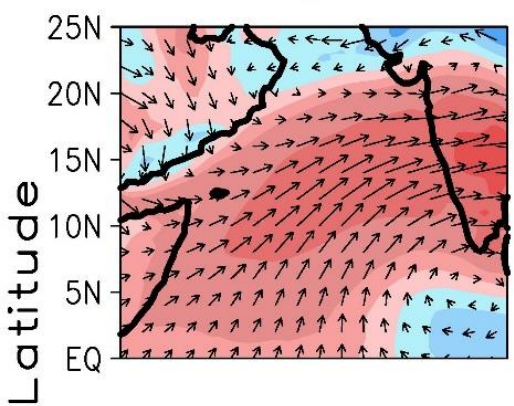

Lag+02

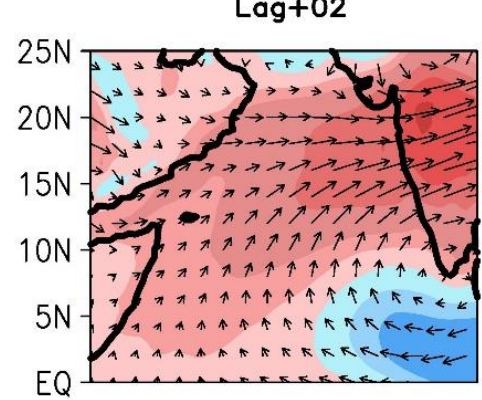

Lag+08

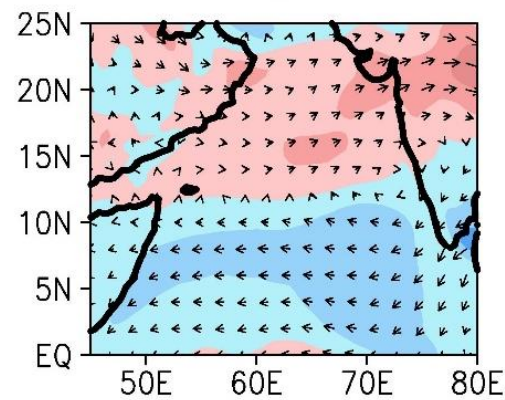

Log-08

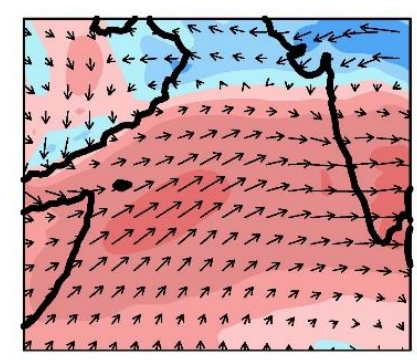

Lag-02

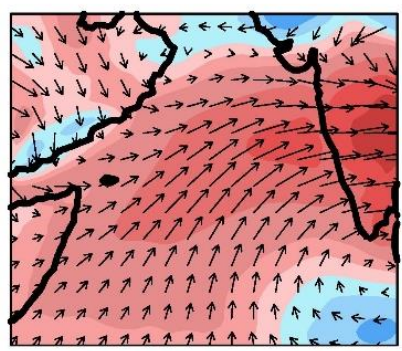

Lag+04

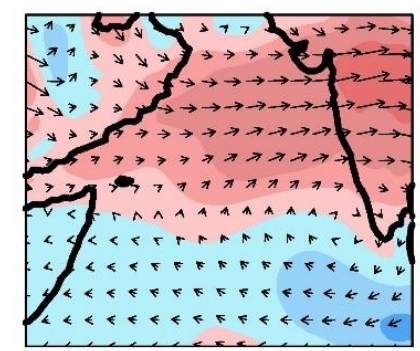

Lag+10

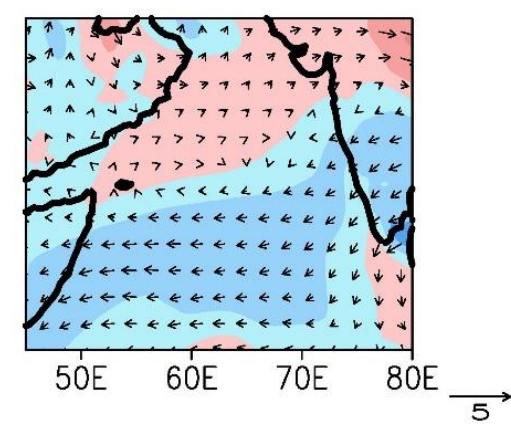

Longitude

5

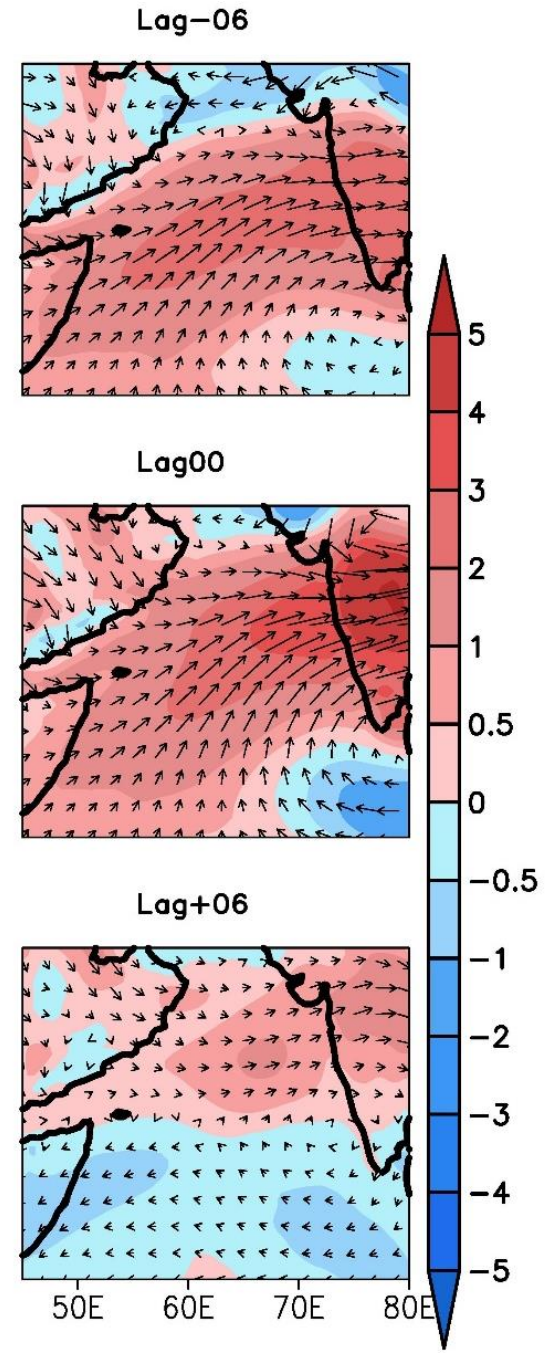


(b)

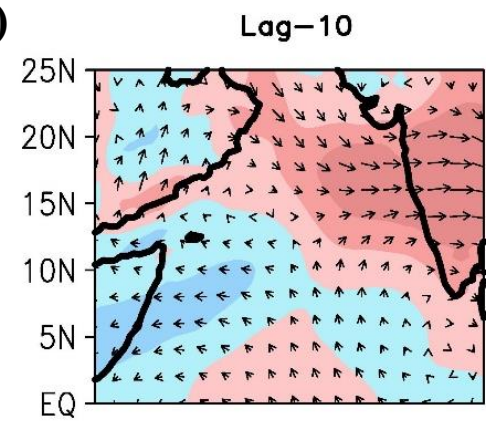

Lag-04

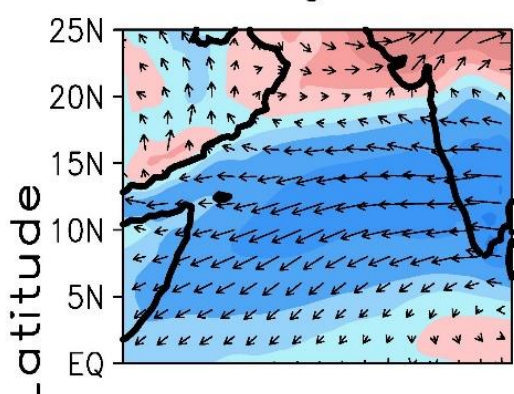

Lag+02

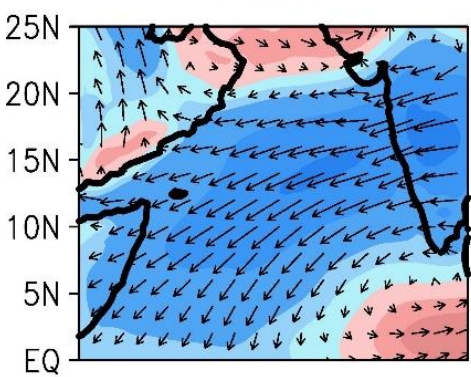

Lag+08

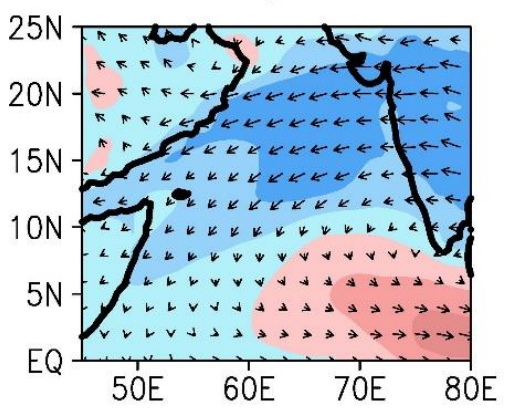

Lag-08

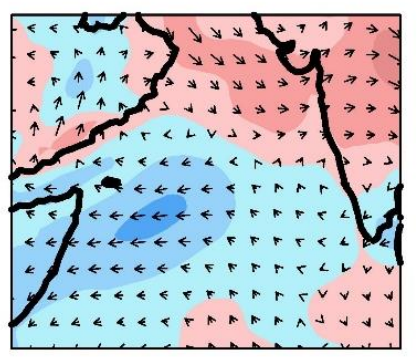

Lag-02

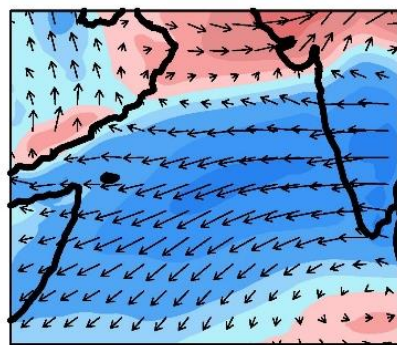

$\operatorname{Lag}+04$

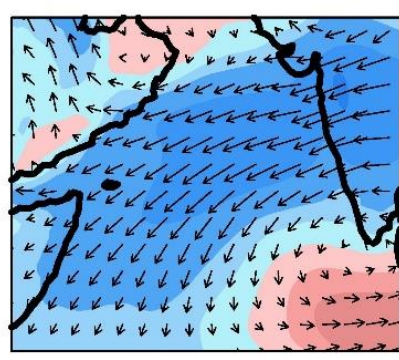

$\operatorname{Lag}+10$

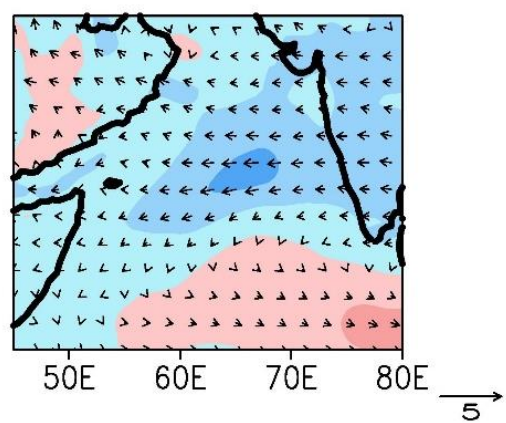

Longitude

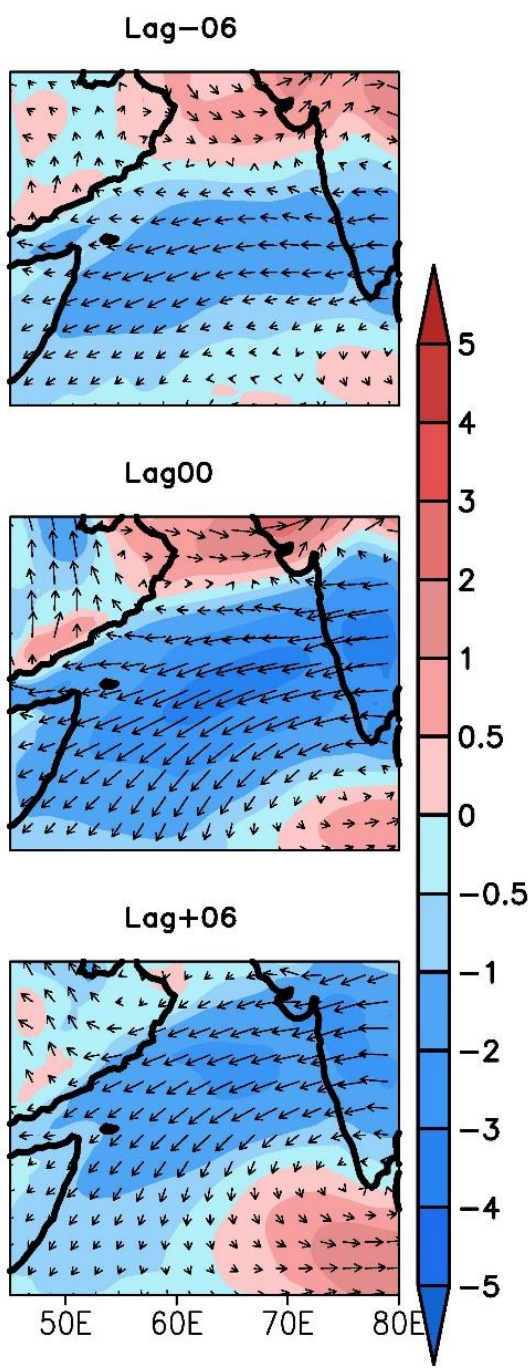

Fig. 3. Time-averaged lagged composite of daily wind anomalies at $850 \mathrm{hPa}$ (magnitude; shaded, vector; $5 \mathrm{~m} / \mathrm{s}$ ) from -10 to +10 lag during Jul and Aug over the region $45^{\circ} \mathrm{E}-80^{\circ} \mathrm{E}$ and $0^{\circ} \mathrm{N}-25^{\circ} \mathrm{N}$ for (a) active, and (b) break periods. 
(a)
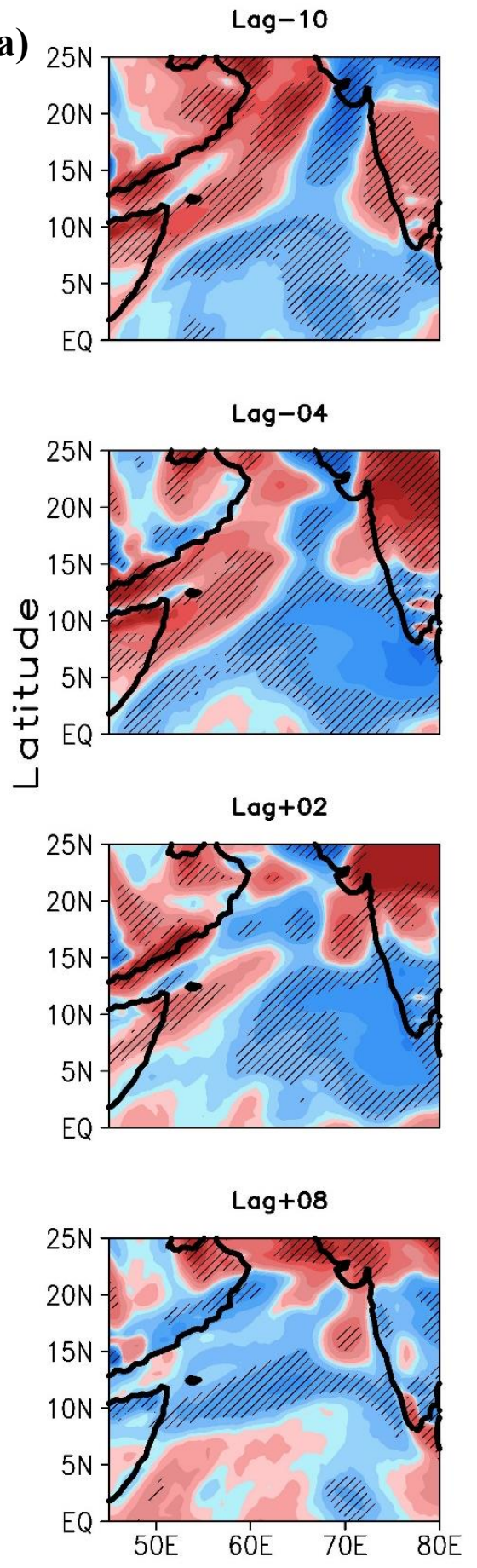
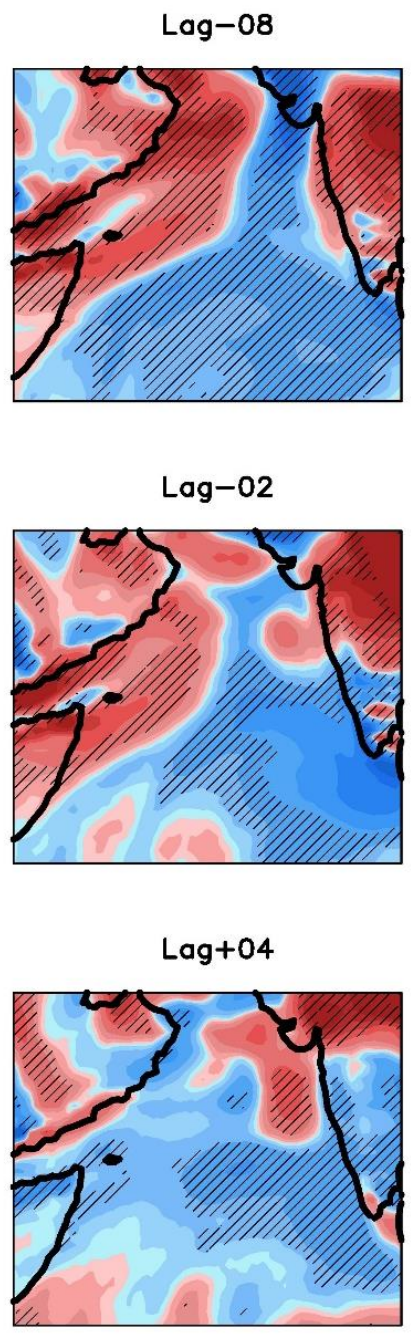

Lag+10

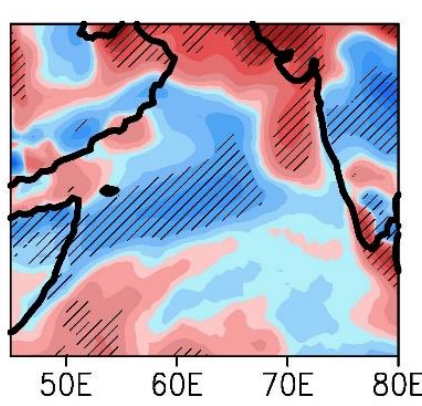

Longitude

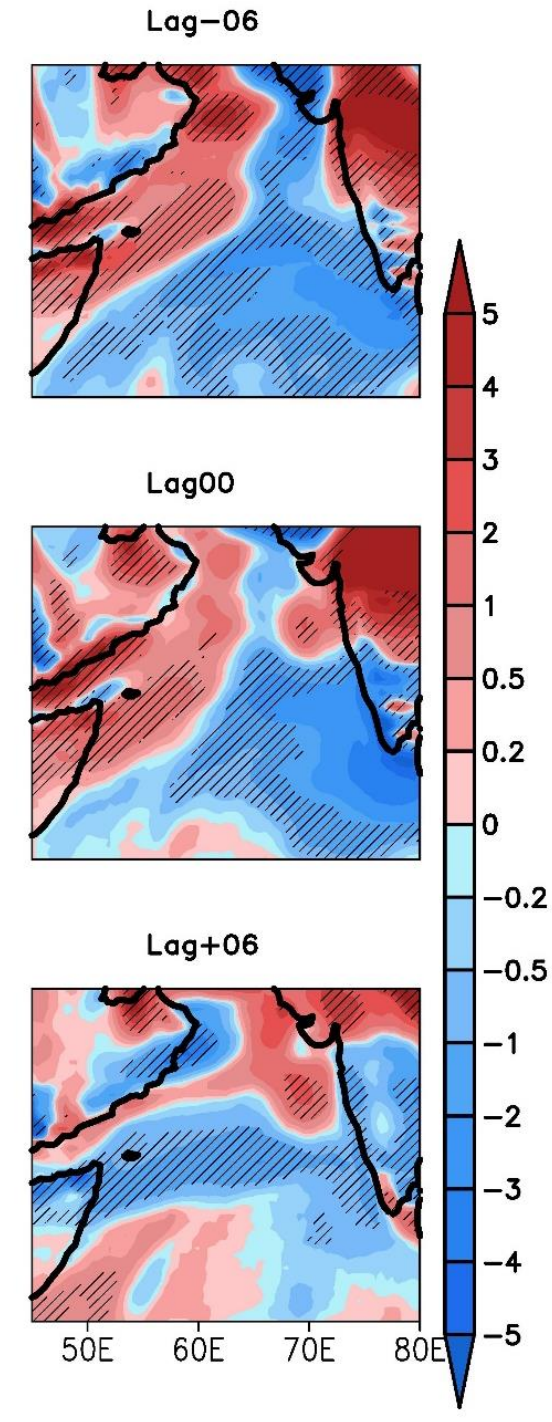



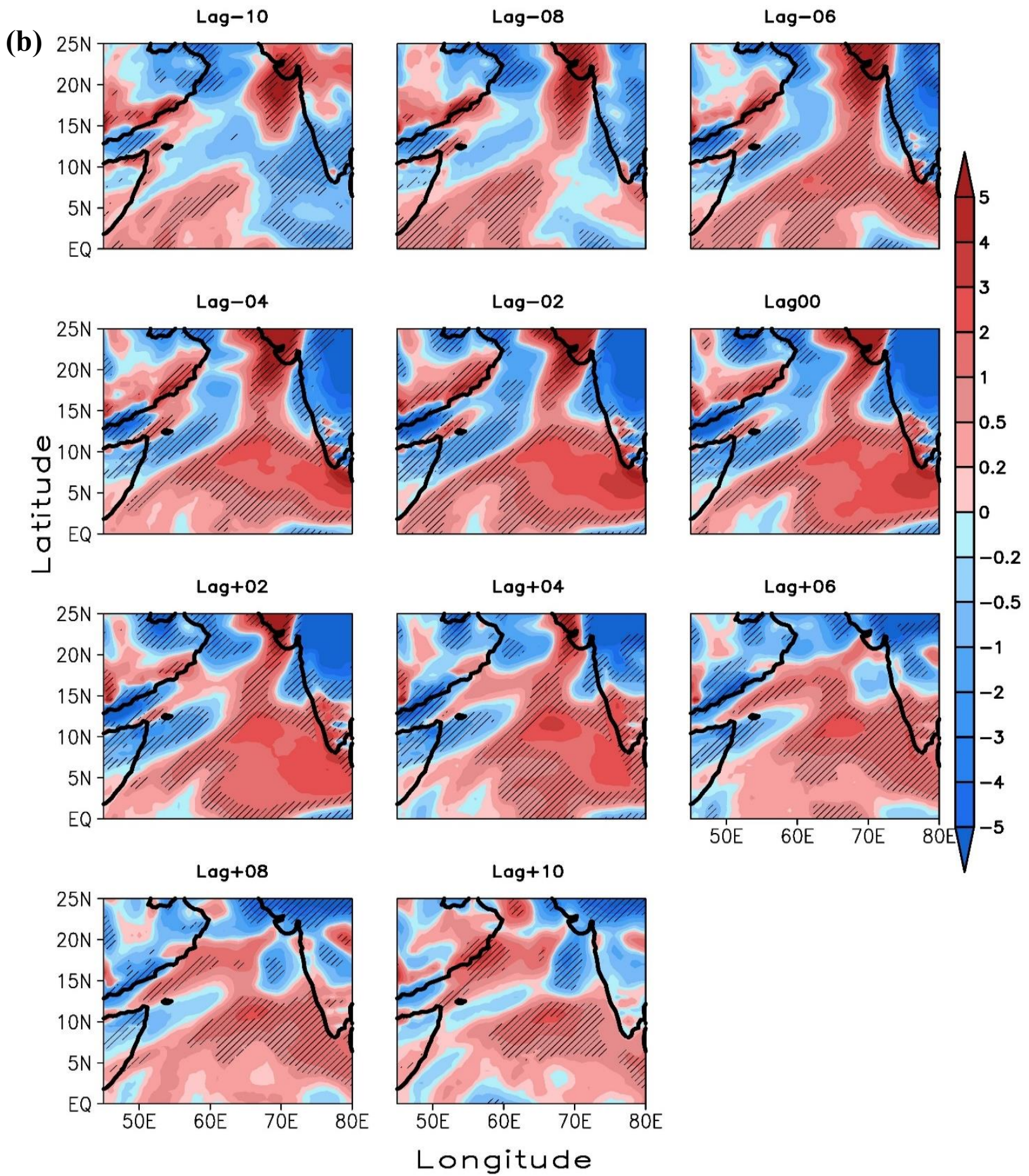

Fig. . Time-averaged lagged composite of daily Somali Jet PV $\left(10^{-8} \mathrm{~m}^{-2} \mathrm{~s}^{-1} \mathrm{~K} \mathrm{~kg} \mathrm{k}^{-1}\right)$ anomalies at $850 \mathrm{hPa}$ from -10 to $+10 \mathrm{lag}$ for period during Jul and Aug over the region $45^{\circ} \mathrm{E}-80^{\circ} \mathrm{E}$ and $0^{\circ} \mathrm{N}$ $25^{\circ} \mathrm{N}$ for (a) active, and (b) break periods. The hatched region corresponds to $\geq 95 \%$ significance. 

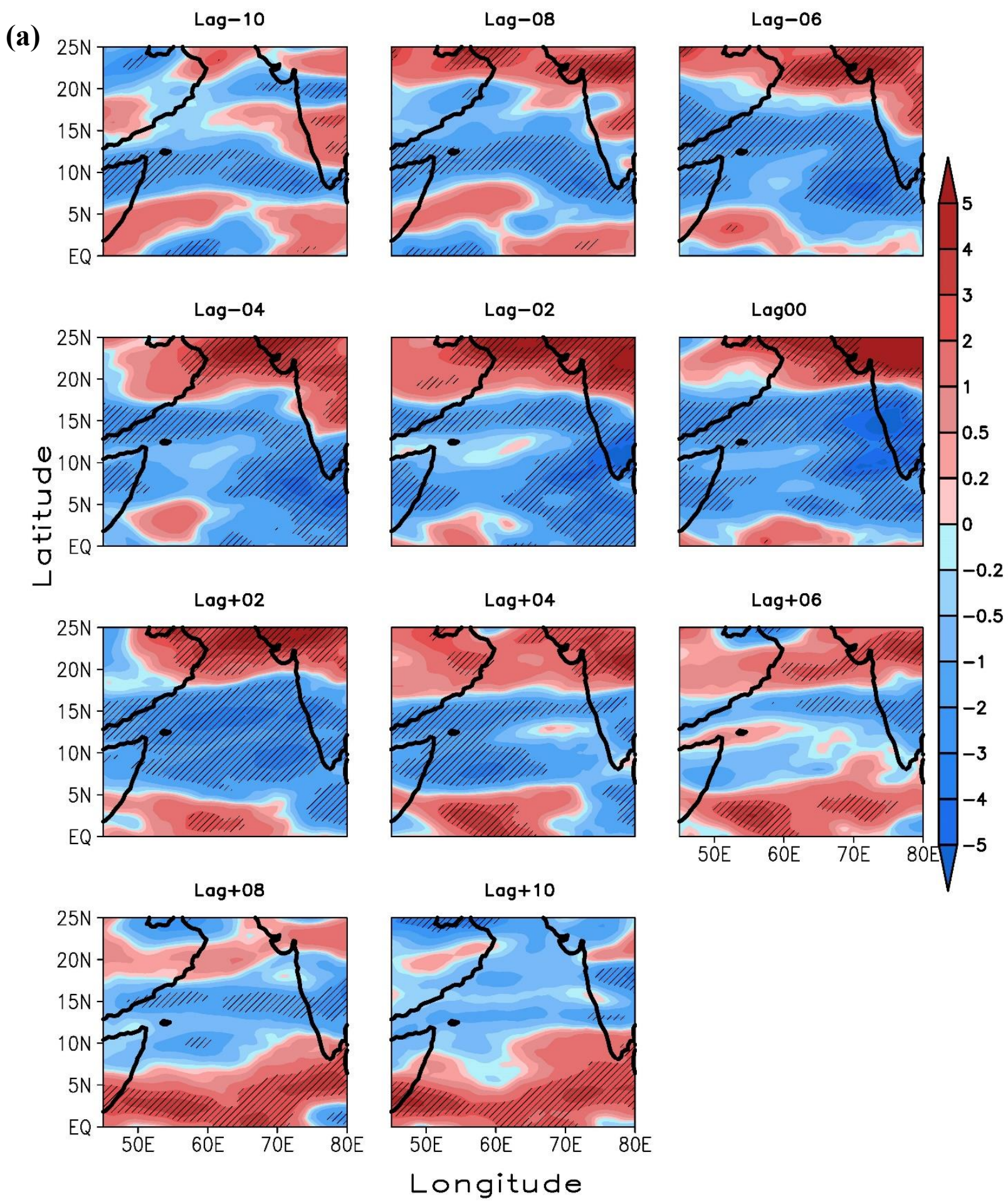
(b)
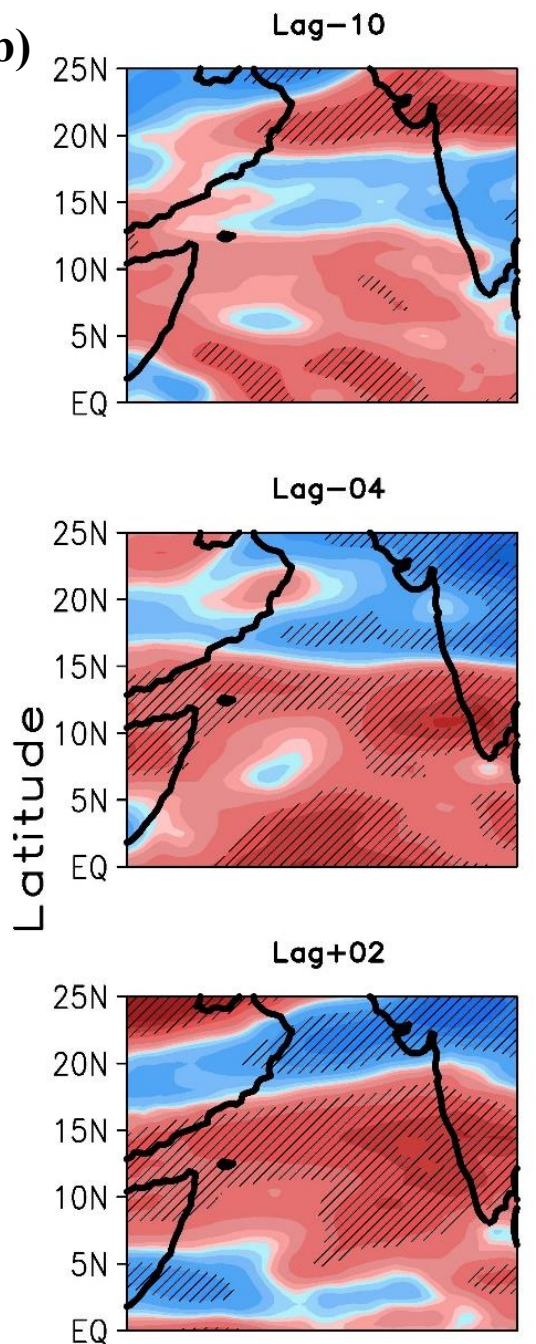

$\operatorname{Lag}+08$

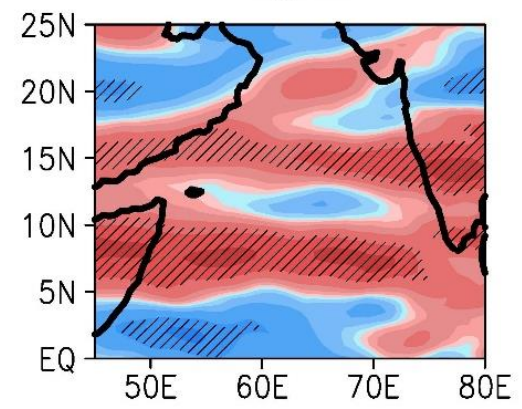

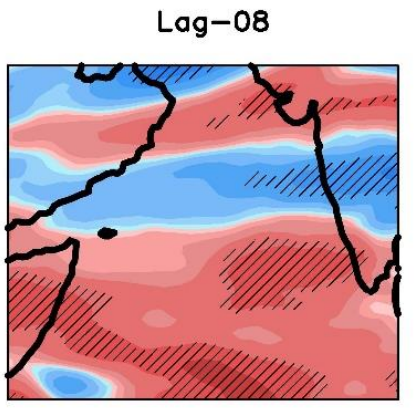
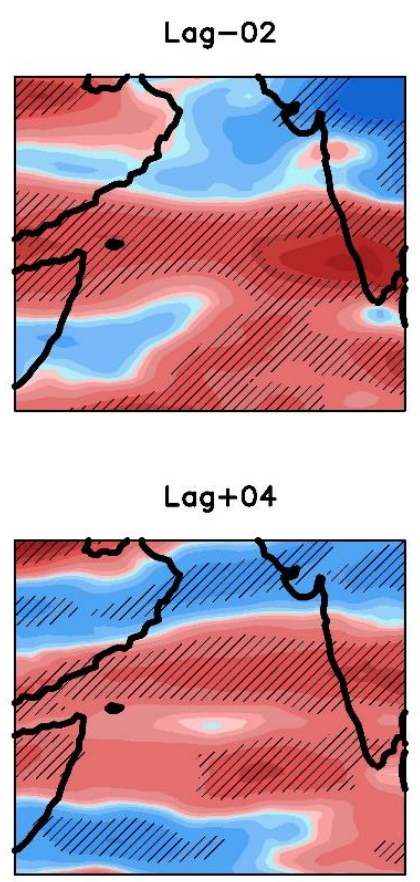

$\operatorname{Lag}+10$

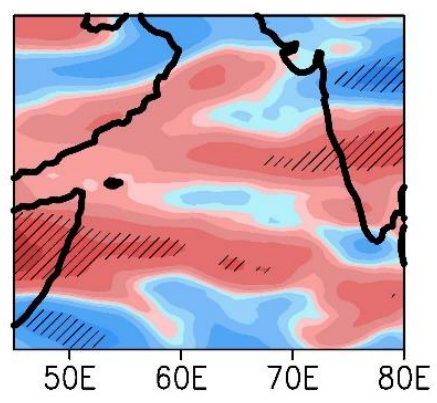

Longitude

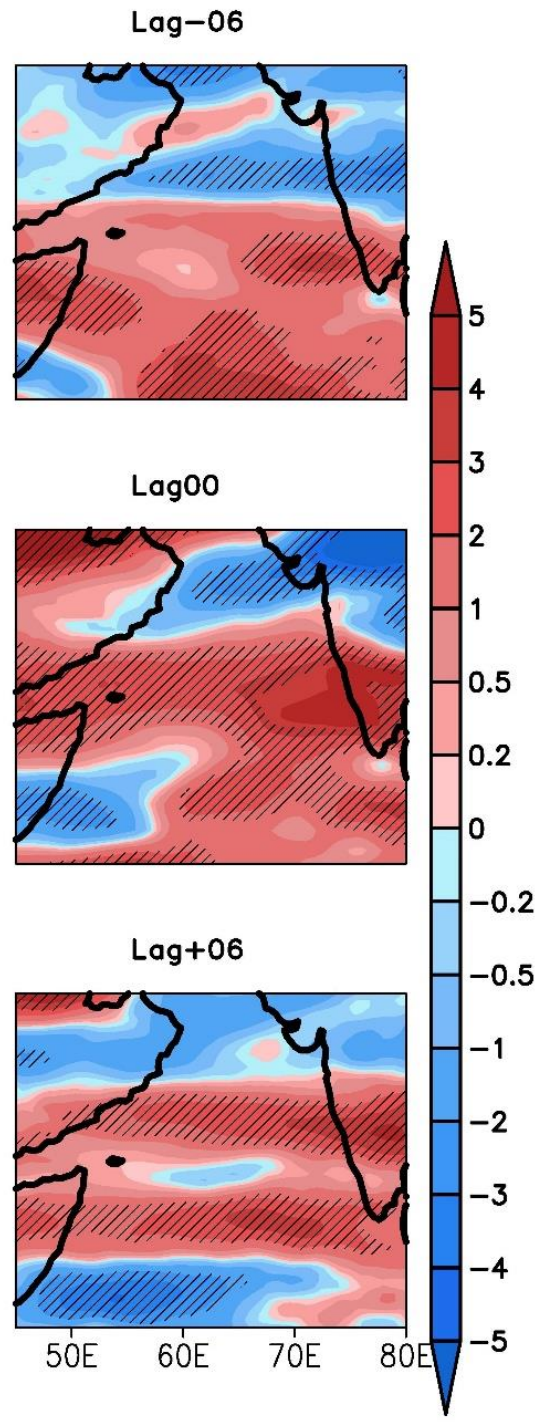

Fig. 5. Time-averaged lagged composite of daily Somali Jet PV $\left(10^{-8} \mathrm{~m}^{-2} \mathrm{~s}^{-1} \mathrm{~K} \mathrm{~kg}^{-1}\right)$ anomalies at $500 \mathrm{hPa}$ from -10 to $+10 \mathrm{lag}$ for period during Jul and Aug over the region $45^{\circ} \mathrm{E}-80^{\circ} \mathrm{E}$ and $0^{\circ} \mathrm{N}-$ $25^{\circ} \mathrm{N}$ for (a) active, and (b) break periods. The hatched region corresponds to $\geq 95 \%$ significance. 


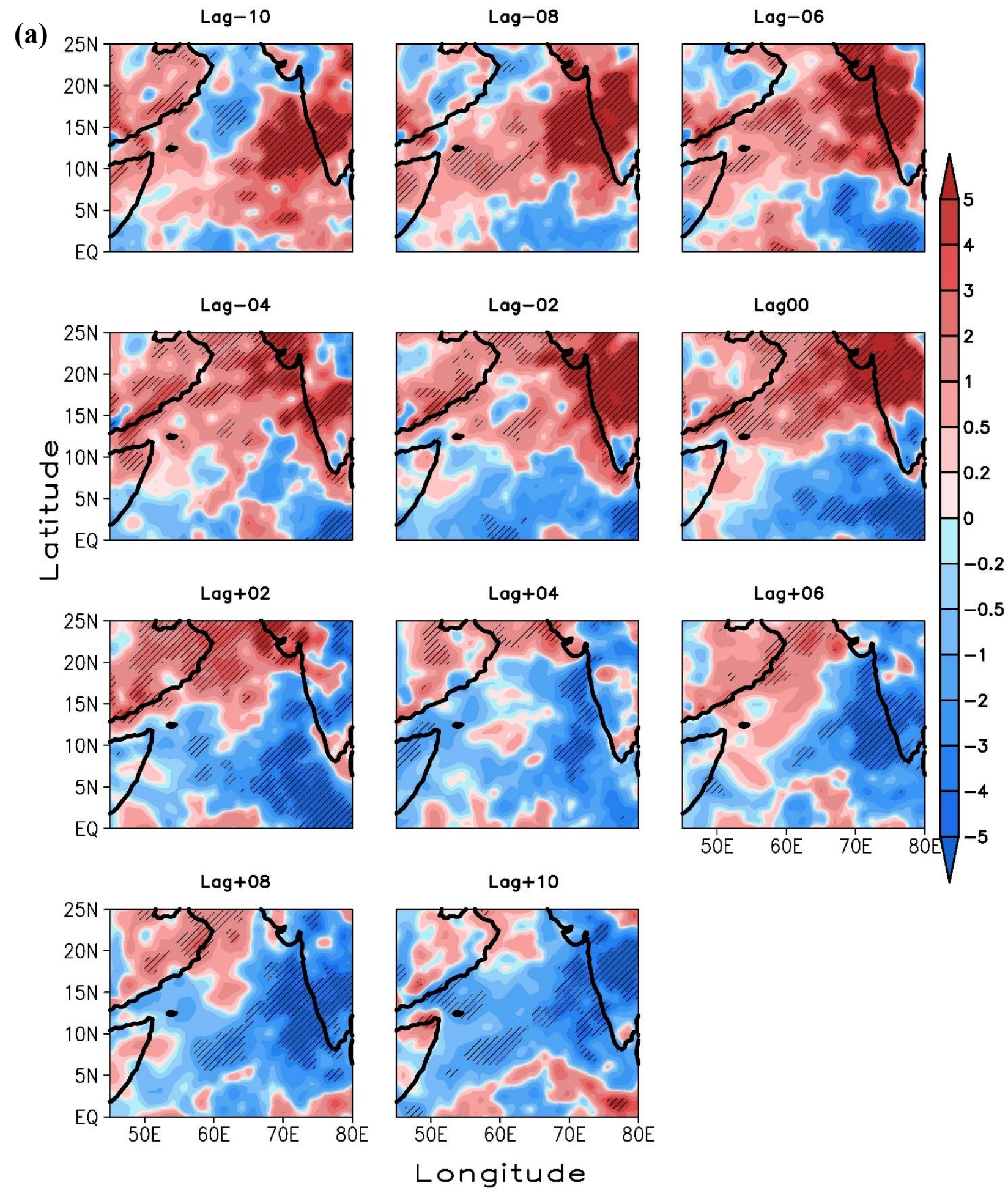


(b)
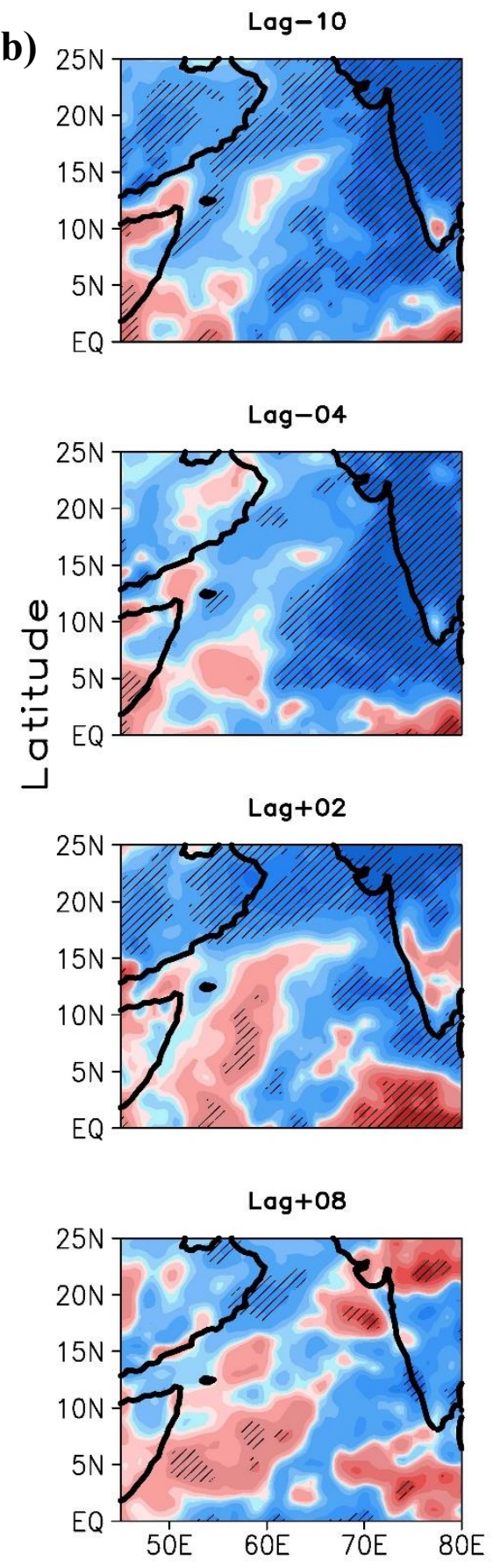
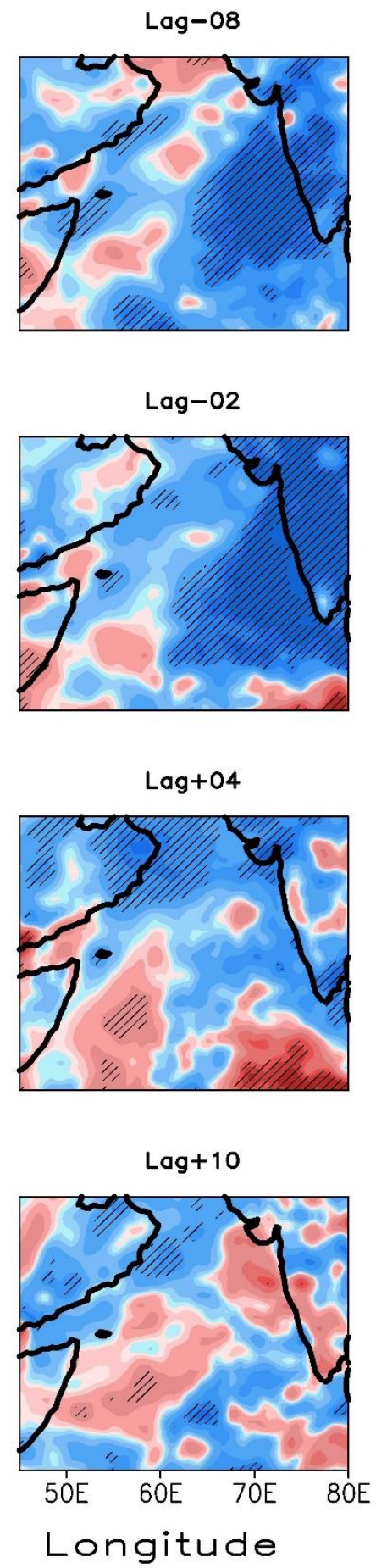

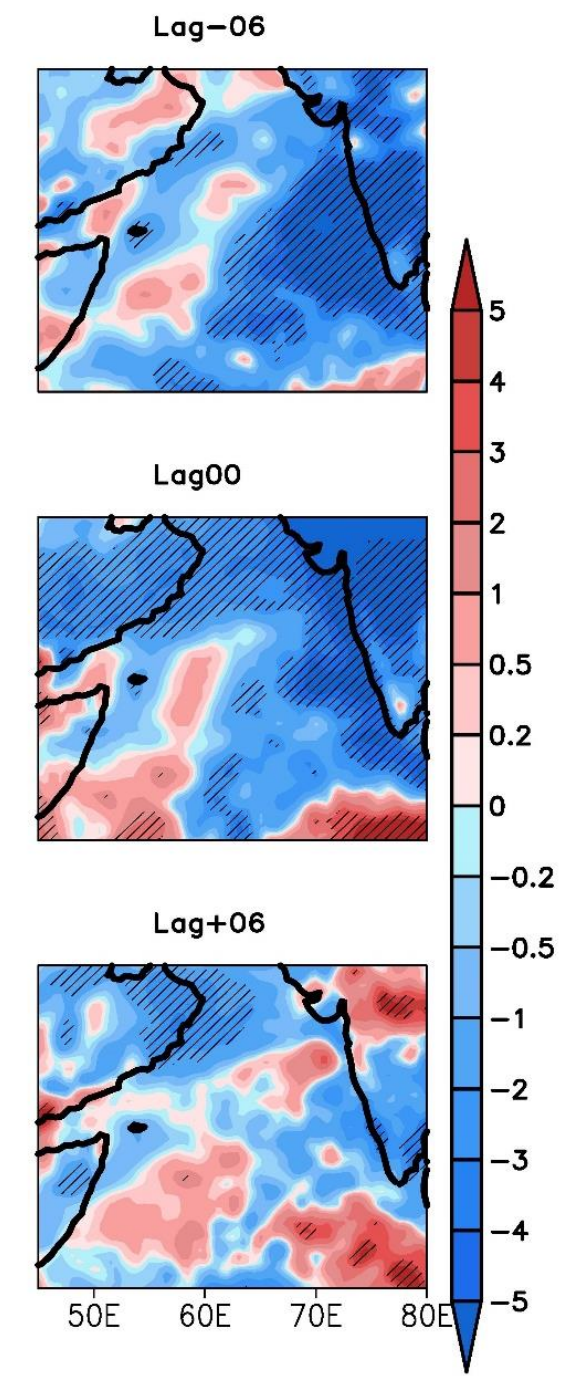

Fig 6. Time averaged lagged composite of daily diabatic heating anomalies at $850 \mathrm{hPa}(\mathrm{K} /$ day) from -10 to +10 lag for period during Jul and Aug over the region $45^{\circ} \mathrm{E}-80^{\circ} \mathrm{E}$ and $0{ }^{\circ} \mathrm{N}-25^{\circ} \mathrm{N}$ for (a) active, and (b) break period. The hatched region corresponds to $\geq 95 \%$ significance. 

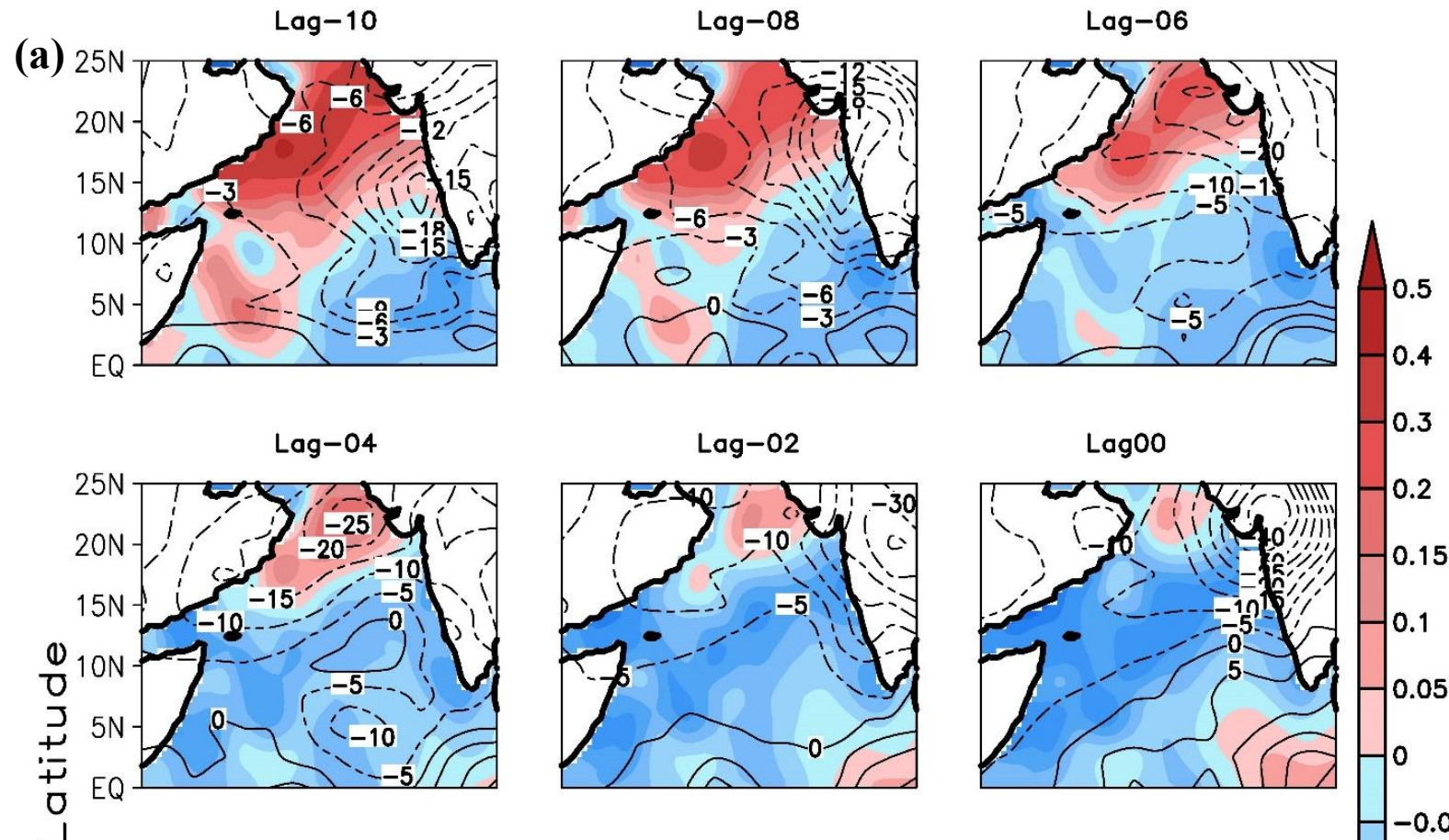

0.3
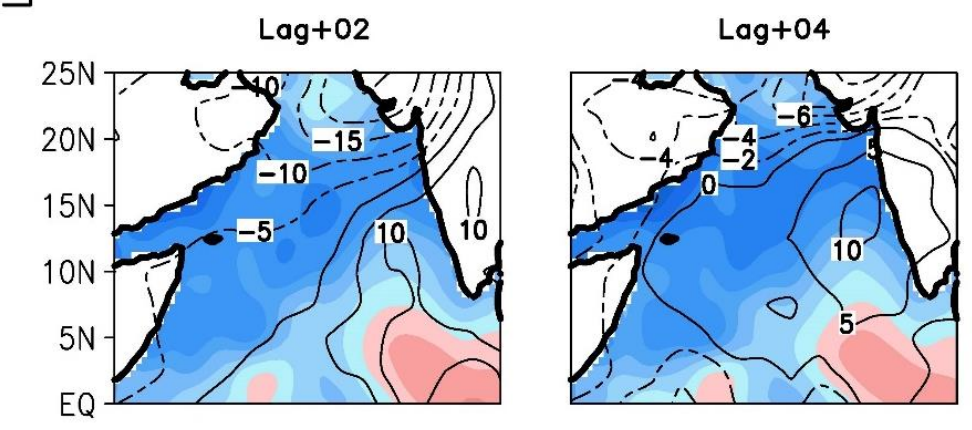

$\operatorname{Lag}+08$ Lag +10
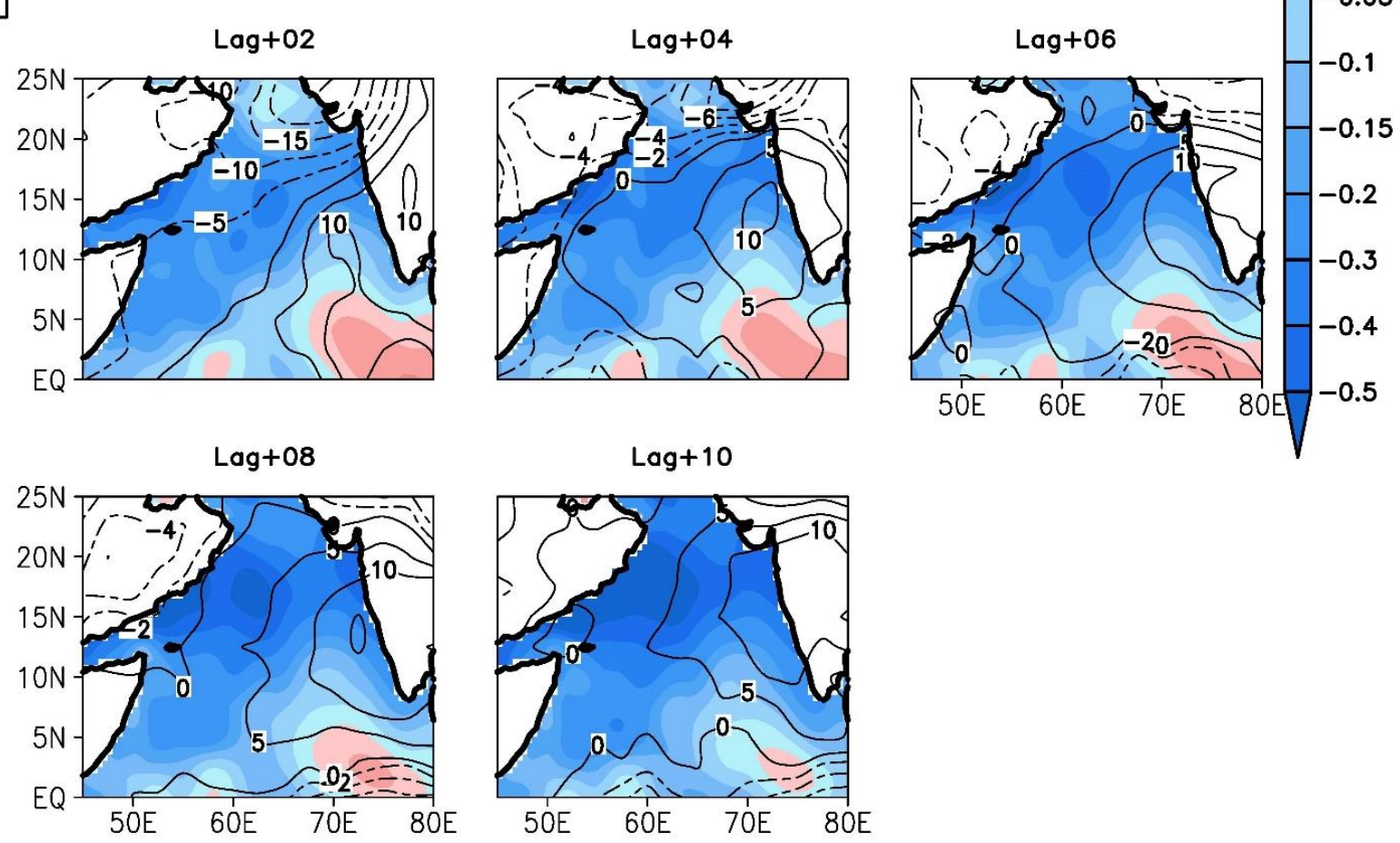

Longitude 

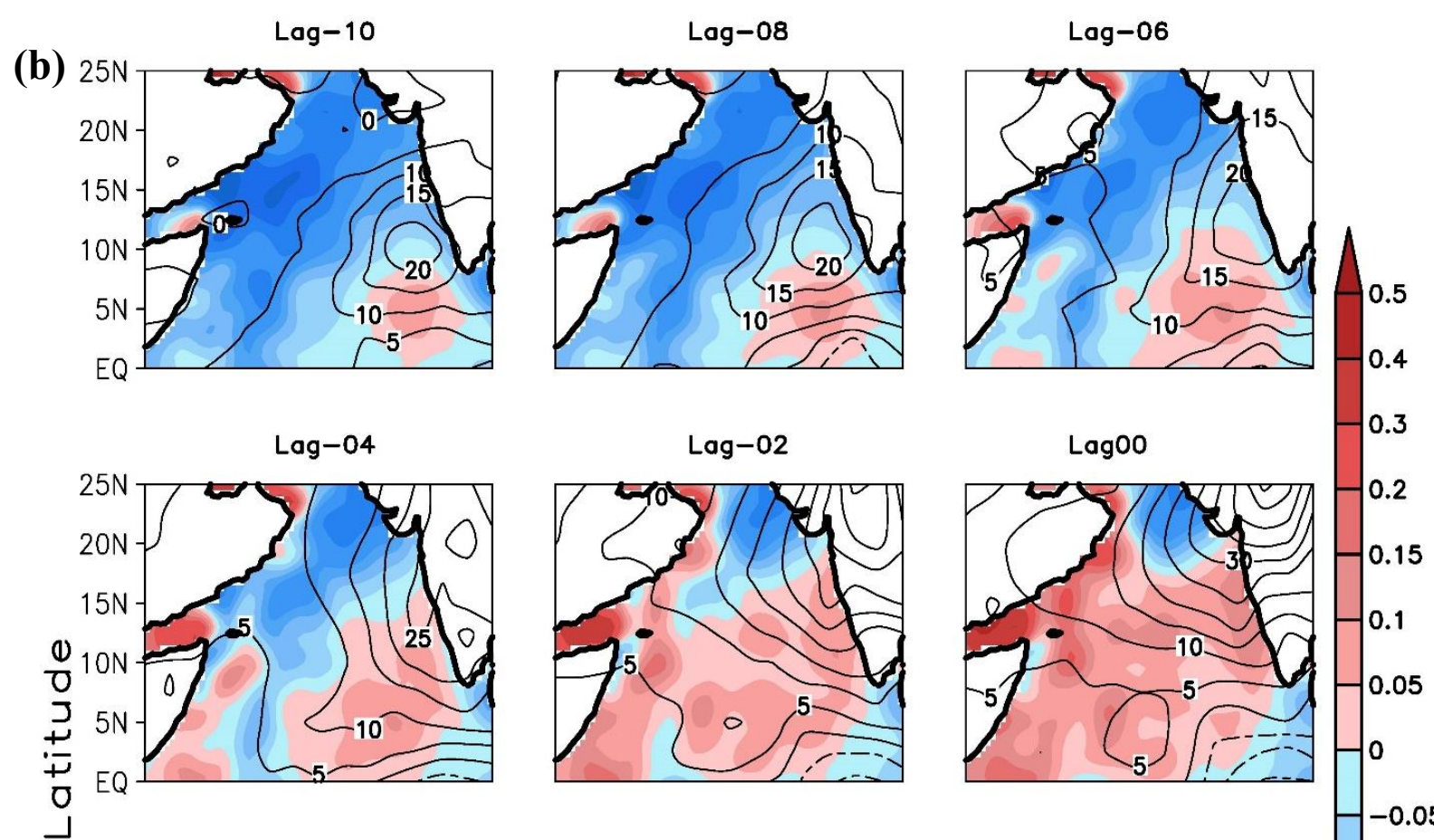

0.3

$-$
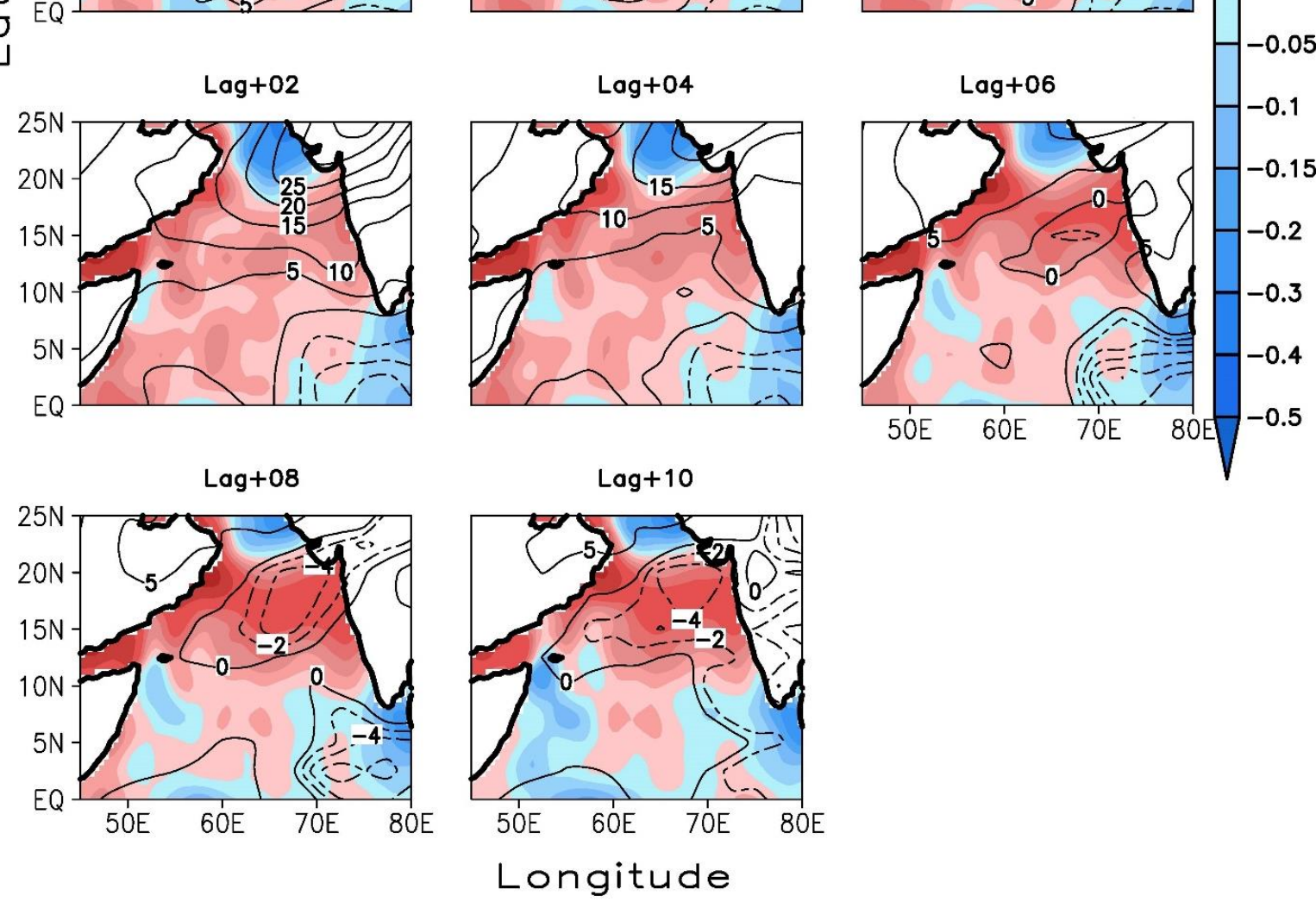

Fig. 7. Time-averaged lagged composite of daily OLR (contour) and SST (shaded) anomalies from -10 to +10 lag during Jul and Aug over the region $45^{\circ} \mathrm{E}-80^{\circ} \mathrm{E}$ and $0^{\circ} \mathrm{N}-25^{\circ} \mathrm{N}$ for (a) active, and (b) break periods. 
(a)
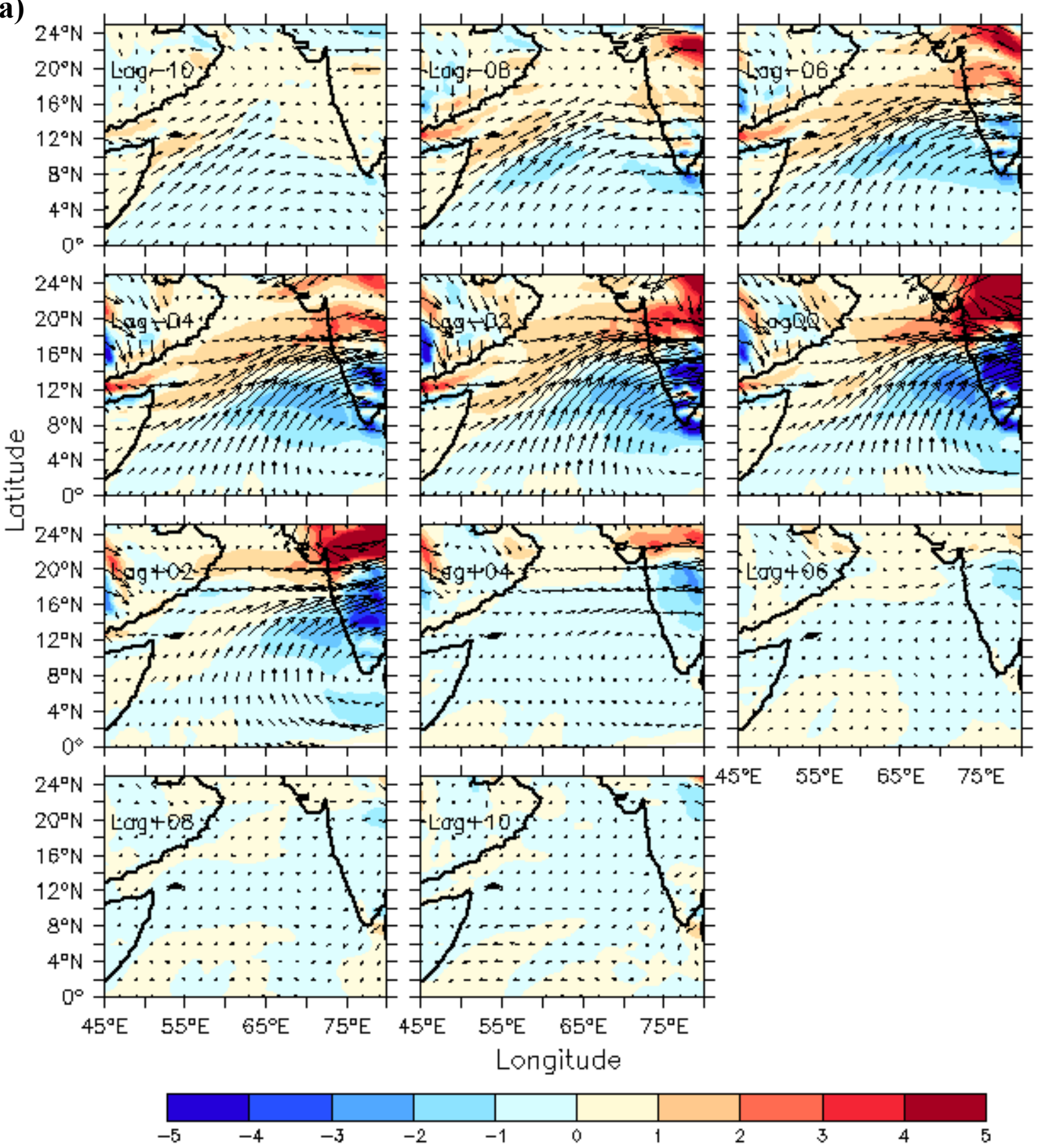

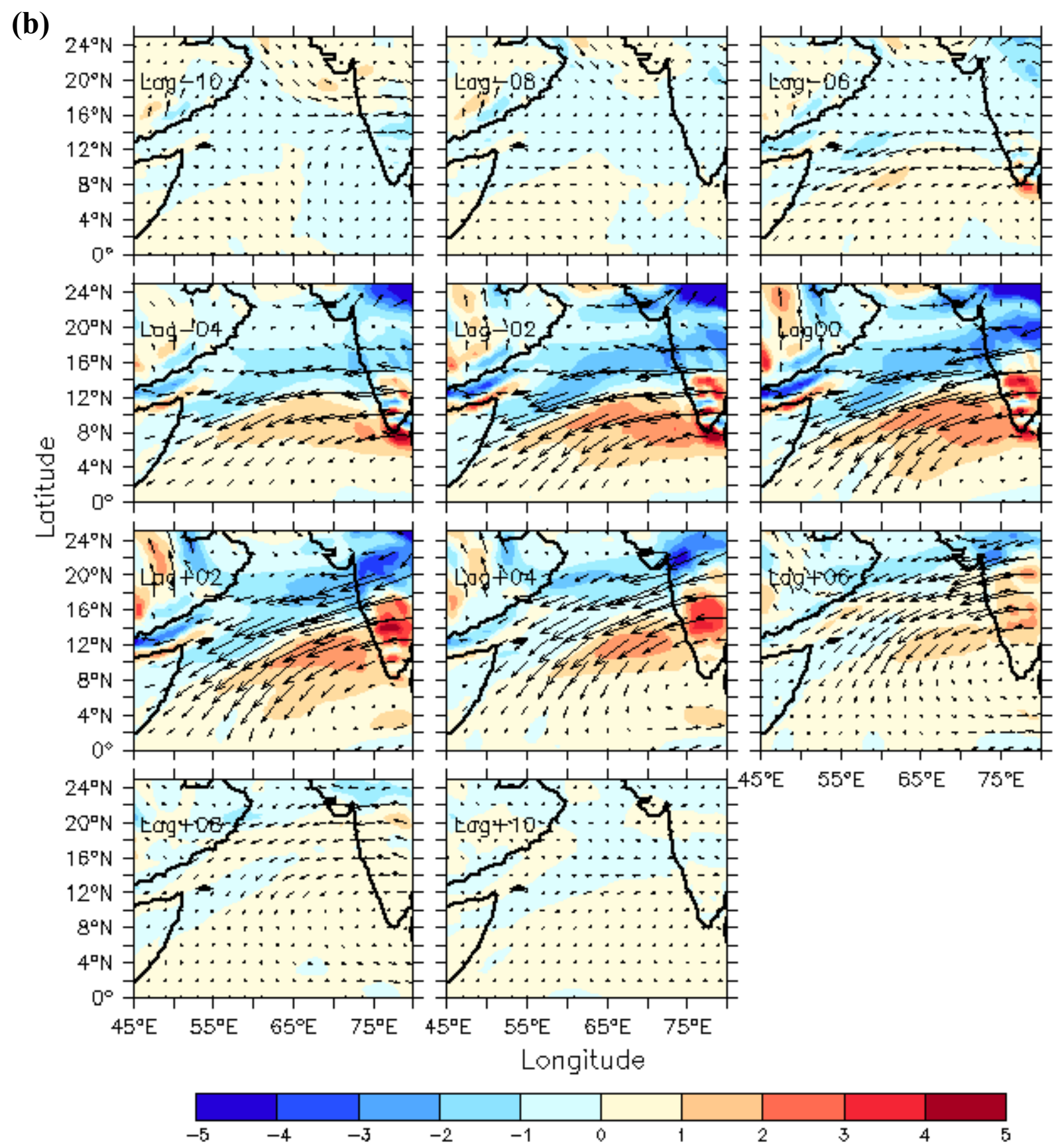

Fig. 8. Time-averaged lagged composite of wind-stress curl (shading; $1 \mathrm{e}-8 \mathrm{Nm}^{-3}$ ) and wind-stress (vector; $\mathrm{Nm}^{-2}$ ) anomalies from -10 to +10 lag during Jul and Aug over the region $45^{\circ} \mathrm{E}-80^{\circ} \mathrm{E}$ and $0^{\circ} \mathrm{N}-25^{\circ} \mathrm{N}$ for (a) active, and (b) break periods. 


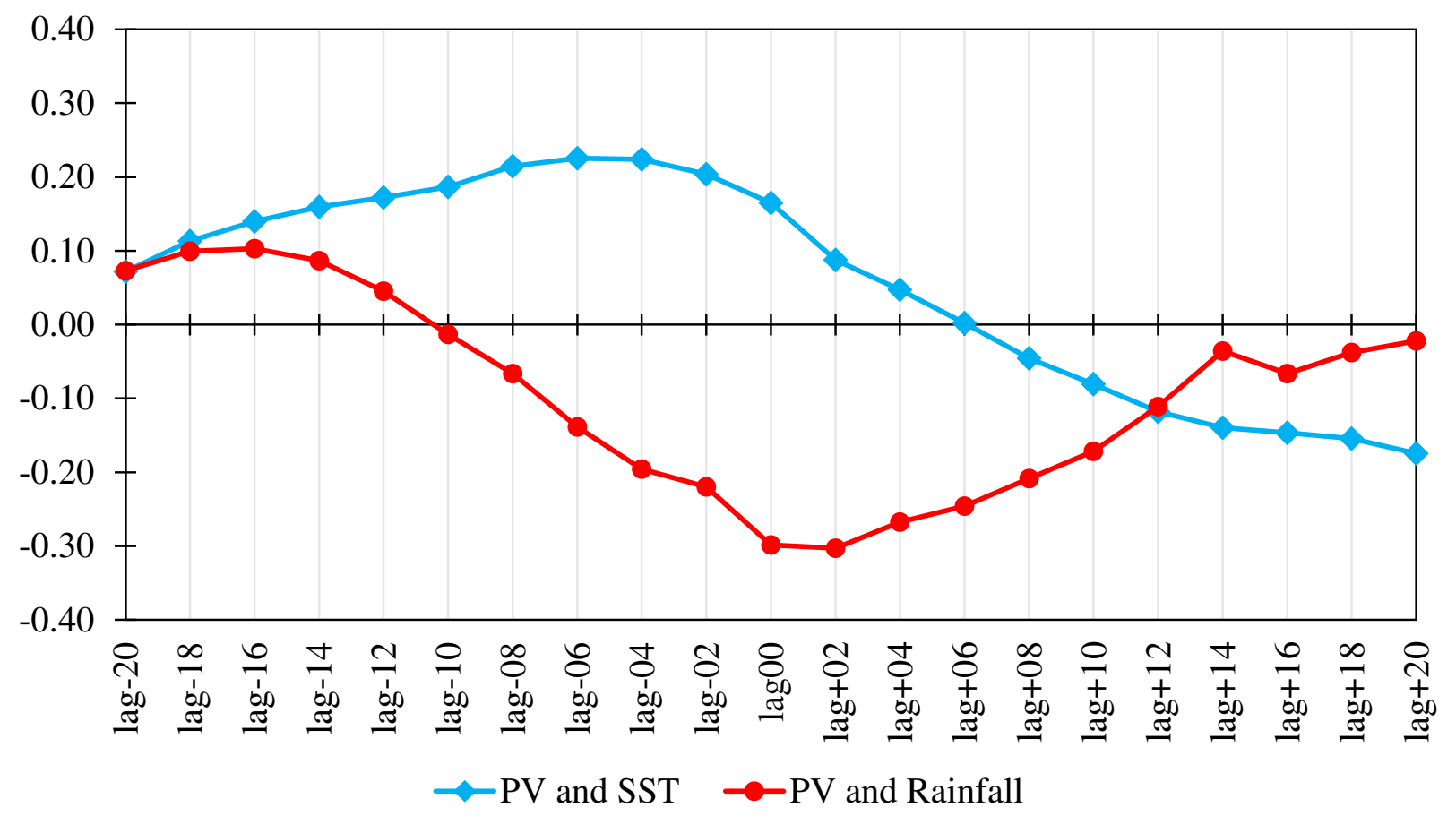

Fig. 9. Lagged correlation between area-averaged PV vs SST (SST shifting) and PV vs Rainfall (Rainfall shifting) for Jul and Aug months over the region $58^{\circ} \mathrm{E}-68^{\circ} \mathrm{E}$ and $6^{\circ} \mathrm{N}-12^{\circ} \mathrm{N}$. 


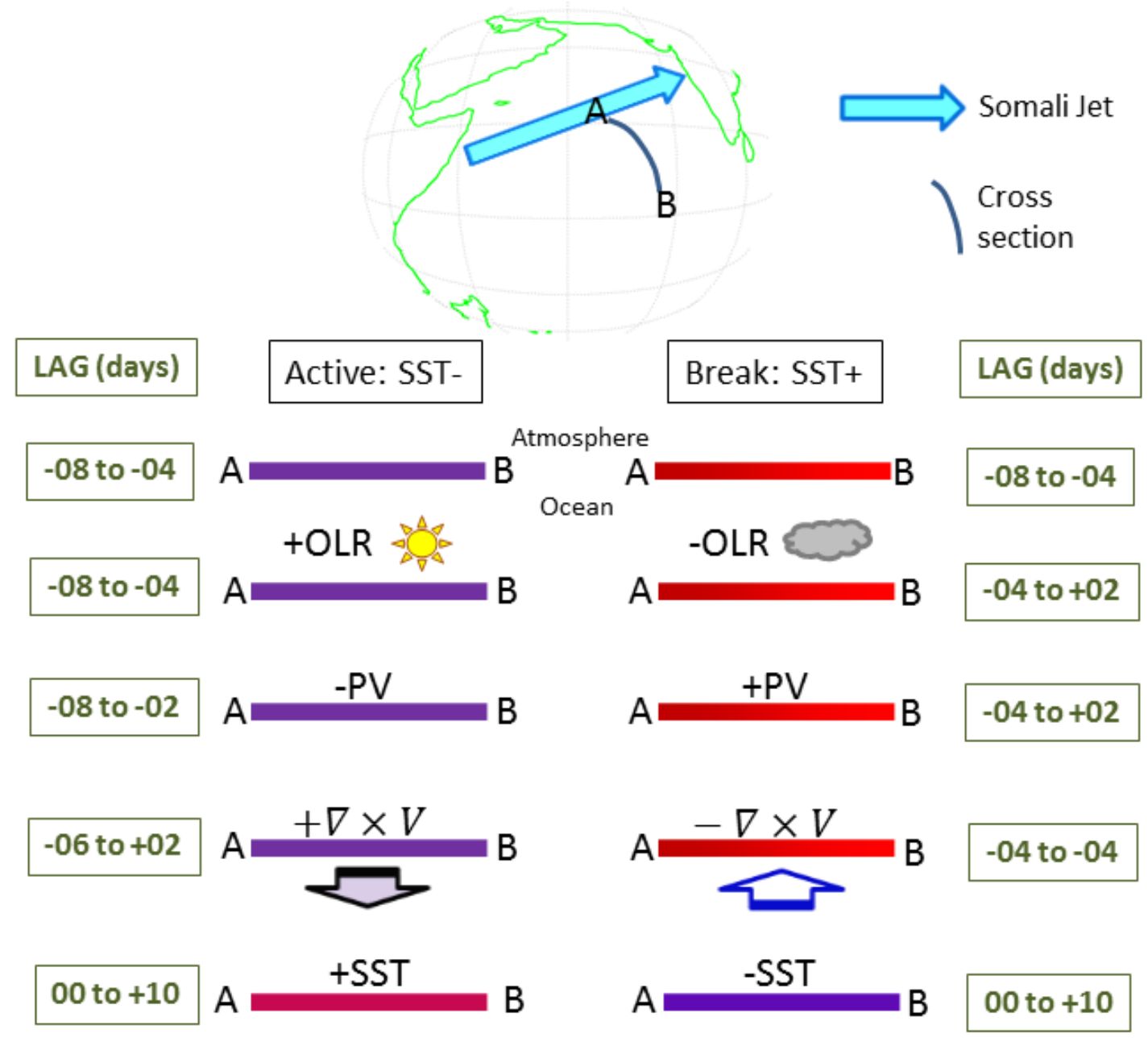

Fig. 10. Schematic showing the development of anomalies in SST, OLR, PV, wind-stress curl, upwelling and resulting SST change on the southern side of the jet in active and break phases. The lag is in days relative to the peak of active and break events as defined by rainfall over the MCR region (see text for full details). 
Table 1. Active and break spells date calculated from IMD observation data at $0.5^{\circ}$ resolution from the period 1979-2005.

\begin{tabular}{|c|c|c|}
\hline Year & Active spell & Break spell \\
\hline 1979 & $3-5 \mathrm{~A}, 7-10 \mathrm{~A}$ & 1-7J, 14-16A, 18-29A \\
\hline 1980 & $1-3 \mathrm{~A}$ & - \\
\hline 1981 & 7-9J, 4-6A & $24-31 \mathrm{~A}$ \\
\hline 1982 & $21-24 \mathrm{~A}$ & $1-8 \mathrm{~J}$ \\
\hline 1983 & $25-27 \mathrm{~J}, 10-15 \mathrm{~A}$ & $7-9 \mathrm{~J}$ \\
\hline 1984 & $2-4 \mathrm{~A}, 9-11 \mathrm{~A}, 16-19 \mathrm{~A}$ & $10-12 \mathrm{~J}, 27-30 \mathrm{~J}$ \\
\hline 1985 & 15-17J, 30J-1A, 7-9A & $1-4 \mathrm{~J}, 22-29 \mathrm{~A}$ \\
\hline 1986 & $21-24 \mathrm{~J}, 12-15 \mathrm{~A}$ & 1-6J, 23-31A \\
\hline 1987 & $24-26 \mathrm{~A}$ & 16-19J, 31J-4A \\
\hline 1988 & $25-27 \mathrm{~J}$ & - \\
\hline 1989 & $21-24 \mathrm{~J}$ & $30 \mathrm{~J}-5 \mathrm{~A}$ \\
\hline 1990 & $22-24 \mathrm{~A}$ & - \\
\hline 1991 & $23-25 A$ & $1-4 \mathrm{~J}$ \\
\hline 1992 & $26-29 \mathrm{~J}, 16-21 \mathrm{~A}$ & $3-10 \mathrm{~J}$ \\
\hline 1993 & $15-17 \mathrm{~J}, 3-6 \mathrm{~A}$ & $20-24 \mathrm{~J}, 8-14 \mathrm{~A}, 22-29 \mathrm{~A}$ \\
\hline 1994 & 10-14J, 18-21J & - \\
\hline 1995 & $18-21 \mathrm{~J}, 23-25 \mathrm{~J}$ & $2-7 \mathrm{~J}, 12-16 \mathrm{~A}$ \\
\hline 1996 & $22-28 \mathrm{~J}$ & $1-3 \mathrm{~J}$ \\
\hline 1997 & $25-27 \mathrm{~J}, 30 \mathrm{~J}-2 \mathrm{~A}, 22-25 \mathrm{~A}$ & 14-17A \\
\hline 1998 & $3-6 \mathrm{~J}$ & $22-26 \mathrm{~J}$ \\
\hline 1999 & $19-21 \mathrm{~J}$ & $1-5 \mathrm{~J}, 13-15 \mathrm{~A}, 23-25 \mathrm{~A}$ \\
\hline 2000 & $17-21 \mathrm{~J}$ & $23-25 \mathrm{~J}, 1-8 \mathrm{~A}$ \\
\hline 2001 & $14-16 \mathrm{~A}$ & $26-31 \mathrm{~A}$ \\
\hline 2002 & - & $2-15 \mathrm{~J}, 22-31 \mathrm{~J}, 26-28 \mathrm{~A}$ \\
\hline 2003 & $26-28 \mathrm{~J}$ & - \\
\hline 2004 & 30J-1A, 3-6A, 9-12A & $20-22 \mathrm{~J}, 26-31 \mathrm{~A}$ \\
\hline 2005 & $1-5 \mathrm{~J}, 25-28 \mathrm{~J}, 31 \mathrm{~J}-2 \mathrm{~A}$ & 8-14A, 24-31A \\
\hline
\end{tabular}

